\title{
Prospects of Saffron and its Derivatives in Alzheimer's Disease
}

\author{
Nadia Zandi, MD; Benyamin Pazoki, MD; Nazanin Momeni Roudsari, Pharm D²; Naser-Aldin Lashgari, Pharm D²; Vahid Jamshidi, PhD²; \\ Saeideh Momtaz, PhD ${ }^{3,4,5}$, Amir Hossein Abdolghaffari, PhD $^{2,3,4,5^{*}}$; Shahin Akhondzadeh, PhD $^{6^{*}}$ \\ ${ }^{1}$ Tehran University of Medical Sciences, Tehran, Iran \\ ${ }^{2}$ Department of Toxicology and Pharmacology, Faculty of Pharmacy, Tehran Medical Sciences, Islamic Azad University, Tehran, Iran \\ ${ }^{3}$ Medicinal Plants Research Center, Institute of Medicinal Plants, ACECR, Karaj, Iran \\ ${ }^{4}$ Toxicology and Diseases Group, Pharmaceutical Sciences Research Center (PSRC), The Institute of Pharmaceutical Sciences (TIPS), and \\ Department of Toxicology and Pharmacology, School of Pharmacy, Tehran University of Medical Sciences, Tehran, Iran \\ ${ }^{5}$ Gastrointestinal Pharmacology Interest Group (GPIG), Universal Scientific Education and Research Network (USERN), Tehran, Iran \\ ${ }^{6}$ Psychiatric Research Center, Roozbeh Hospital, Tehran University of Medical Sciences, Tehran, Iran
}

\begin{abstract}
Alzheimer's disease (AD) is a progressive neurodegenerative disorder and the most common form of dementia in the old age population, making it a worldwide concern. Unfortunately, few drugs have been presented for treatment of mild and moderate AD. To meet this need, more effective anti-AD agents are emerging. Accumulating evidence supports the beneficial roles of natural-based products in brain function, neurotransmission, neurogenesis, synaptogenesis, and the prevention of amyloid fibrillation and neuronal injury. Several in vitro, preclinical, and clinical studies suggest that saffron (its bioactive compounds) is a potential nutraceutical with antioxidant, radical scavenging, anti-inflammatory, hypolipidemic, hypotensive, neuroendocrine, and neuroprotective effects. It has also been proposed that saffron may delay the onset of AD, prevent its progression or help to attenuate the symptoms of the disease. Therefore, we performed a comprehensive search on this plant and its derivatives for AD treatment. Saffron and its active constituents interfere with AD by improving learning behavior, spatial memory, and cognitive function; protecting against neuronal loss; inhibiting beta-amyloid aggregation and neurotoxicity; preventing senile plaques and neurofibrillary tangle (NFT) formation; suppressing the acetylcholinesterase (AChE) activity; and reducing neuroinflammation. Given conclusive scientific findings, saffron and its derivatives might counter neurodegenerative diseases through multiple pathways. Further clinical trials are expected to confirm the neuroprotective properties of this herb and also to translate such findings to improve patients' outcomes.

Keywords: Acetylcholinesterase inhibitors, Amyloid beta, Apolipoprotein E, Neurofibrillary tangles, Saffron, Alzheimer's disease Cite this article as: Zandi N, Pazoki B, Momeni Roudsari N, Lashgari N, Jamshidi V, Momtaz S, et al. Prospects of saffron and its derivatives in Alzheimer's disease. Arch Iran Med. 2021;24(3):233-252. doi: 10.34172/aim.2021.35.
\end{abstract}

Received: September 17, 2019, Accepted: October 4, 2020, ePublished: March 1, 2021

\section{Introduction}

Alzheimer's disease (AD) is the main etiology of memory loss, prompting irreversible progressive impairments in cognition and memory. ${ }^{1}$ Both the incidence and prevalence of $\mathrm{AD}$ are increasing worldwide. It is estimated that in 2050, one out of 85 individuals will suffer from AD. ${ }^{2}$ Thus far, several mechanisms have been proposed for $\mathrm{AD}$ induction or progression. The cholinergic hypothesis refers to reduction of acetylcholine (ACh) in the central cortex of the brain - an area that involves functional skills. ${ }^{3}$ Hence, acetylcholinesterase (AChE) inhibitors like donepezil have been found effective in improving mild and moderate to severe $\mathrm{AD}$ symptoms. ${ }^{3}$ The amyloid cascade hypothesis $(\mathrm{ACH})$ suggests a lack of balance between production and clearance of amyloid-beta $(A \beta)$, which leads to nerve cell dysfunction and death. ${ }^{4}$ On the other hand, intracellular neurofibrillary tangles (NFTs) block neurotransmitters and cause neuronal cell death. ${ }^{5}$ Tau oligomers are accumulated in $\beta$-sheet conformation and produce NFTs. ${ }^{6}$ Also, high concentration of $A \beta$ triggers NFT formation, and accumulation of NFTs in neurons lead to cell death. ${ }^{7}$ Another hypothesis points to the fact that the $\varepsilon 4$ and $\varepsilon 3$ carriers of the apolipoprotein $\mathrm{E}$ gene $(A P O E)$ are more prone to $\mathrm{AD}$; notwithstanding, the $\varepsilon 4$ allele is the main genetic risk factor for late-onset $\mathrm{AD}$. Apolipoprotein E (ApoE) is known to regulate lipid and protein homeostasis in the brain. ${ }^{8-10}$ In addition to ApoE, several other genes have also been implicated in $\mathrm{AD}$ such as polymorphisms in sortilin related receptor 1 (SORL1), clusterin, complement component receptor 1 (CCR1), Cluster of differentiation 2 associated protein (CD2AP), Cluster of differentiation 33 (CD33), Ephrin type-A

*Corresponding Author: Shahin Akhondzadeh, PhD; Psychiatric Research Center, Roozbeh Psychiatric Hospital, Tehran University of Medical Sciences, South Karf gar Street, Tehran, Iran. Email: s.akhond@neda.net

Amir Hossein Abdolghaffari, Department of Toxicology and Pharmacology, Faculty of Pharmacy, Tehran Medical Sciences, Islamic Azad University, Tehran, Iran, No. 99, Yakhchal, Gholhak, Shariati St., P. O. Box: 19419-33111, Tehran, Iran. Tel: +98 21 22640051-5, Fax: +98 21 22602059, Email: amirhosein172@hotmail.com 
receptor 1 (EPHA1), and Membrane spanning 4-domains A6E (MS4A4/MS4A6E) genes. ${ }^{11}$

Oxidative stress and free radicals are effective factors for behavior and memory impairments in agerelated neurodegenerative disease. ${ }^{12}$ Genetic factors, ${ }^{13}$ neuroinflammation, ${ }^{14}$ type 2 diabetes, environmental factors, stroke, and $\operatorname{diet}^{15,16}$ have also been proven to be involved in $\mathrm{AD}$ onset and/or progression, although aging is still the main risk factor for $\mathrm{AD} .{ }^{17}$

Considering the shortcomings of current treatments for late-onset $\mathrm{AD}$ and regarding the positive impact of plant species in AD treatment (i.e. Melissa officinalis, Nigella sativa, Boswellia spp. and Cinnamon spp.) natural products are considered as high priorities for treatment of neurodegenerative diseases. ${ }^{18}$ Saffron is one of the spices extracted from stigmas of the Persian herb Crocus sativus L. and is usually used in cooking ${ }^{19}$ and contains four main constituents; safranal, crocin, crocetin, and picrocrocin.

Traditionally, saffron is used for gingival sedation, catarrhal healing, expectoration, improving appetite and digestion, nerve sedation and anticonvulsant, improving sweating, and as antispasmodic. ${ }^{20,21}$ During the past two decades, various clinical and experimental studies have revealed that saffron and its bioactive constituents have therapeutic functions as anticonvulsant, anti-hypertensive, anti-spasmodic, ${ }^{22}$ cardioprotective, anti-atherosclerotic, ${ }^{23}$ anticancer, ${ }^{24}$ antidiabetic, ${ }^{25}$ antioxidant, antiparasitic, ${ }^{26}$ anti-inflammatory, analgesic, ${ }^{27}$ and immunomodulators. ${ }^{28}$ They might be involved in modulation of smooth muscles, ${ }^{29}$ gastrointestinal, ${ }^{30}$ respiratory, ${ }^{31}$ and reproductive ${ }^{32}$ systems. Up to now, the majority of pharmacological experiments on saffron and/or its components have focused on their probable significant effects on CNS. The antidepressant, ${ }^{33}$ anticonvulsant, ${ }^{34}$ and antianxiety properties of saffron were reported, while it may improve memory impairments, tremor, ${ }^{35}$ opioid withdrawal syndrome, ${ }^{36}$ and was shown to have a broad spectrum of protective effects on the CNS. The stigmas, corms and phytochemicals of Crocus sativus could improve neuronal impairments, ${ }^{37,38}$ such as Parkinson's disease, by reduction of dopamine in the substantia nigra, ${ }^{39}$ suppression of neurotoxicity by diminishing oxidative damage, ${ }^{40,41}$ repression of neuroinflammation due to increased intraocular pressure in order to avert retinal ganglion cell death in patients with glaucoma, ${ }^{42}$ and improvement of neurodegenerative retinal diseases ${ }^{43}$ and visual function in age-related macular degeneration patients. ${ }^{44}$ In vivo, administration of saffron improved memory impairment induced by ethanol, aluminum (Al), morphine, ketamine, and arsenic. ${ }^{41,45-48}$ Extracts of saffron stigma have been presented to have antioxidant and anti-amyloidogenic functions and also inhibited $A \beta$ aggregation and deposition. ${ }^{21,49}$

\section{Active Constituents of Saffron}

Phytochemical analysis showed that saffron contains nearly
150 volatile and some nonvolatile compounds, of which only a few have already been identified. Apocarotenoid glycosides (i.e. crocin); picrocrocin; volatile oil (i.e. safranal); carotenoids; lycopene; alpha-, beta-, and gammacarotene; fatty oil and starch are the main constituents of this plant. ${ }^{50}$ Crocin, and crocetin belong to carotenoids, while picrocrocin and safranal are monoterpene aldehydes. Crocin is a glucosyl ester of crocetin and the compound responsible for the red color of Crocus sativus. However, picrocrocin, a glycoside of safranal, provides the unpleasant taste of Crocus sativus. Safranal is the main component of saffron and is associated with its aroma. ${ }^{48}$ Crocin and safranal isomers have bioactive properties for better absorption in the intestinal lumen. ${ }^{51-53}$ It was shown that saffron hydrolyzes to trans-crocetin by intestinal enzymes immediately after the entrance to the lumen and absorbed through the intestinal wall by passive diffusion. ${ }^{54,55}$ Crocin is not absorbed orally, after a single dose or repeated doses, but its oral administration produces a higher level of crocetin in comparison with intravenous administration. ${ }^{56}$ However, crocin is highly detected in the intestinal tract following oral administration. Crocin can hydrolyze to crocetin when used orally, then the absorbed crocetin is partially metabolized to mono- and di-glucuronide conjugates. ${ }^{55,57}$ Crocetin's affinity for binding to albumin is low, which facilitates its transmission to different tissues and helps to cross the blood brain barrier via transcellular diffusion more easily. ${ }^{54,57,58}$ According to a recent study in 2019, fast intestinal absorption of saffron extracts leads to a higher serum level of crocetin compared with intravenous administration. ${ }^{59}$ The active components of saffron have been shown to possess antidepressant and antitumor effects, while they are able to neutralize free radicals and reduce inflammation. ${ }^{20,21}$ Taken together, saffron might be a candidate for research on neurodegenerative diseases. Therefore, this review provides an overview of recently published clinical, preclinical, and experimental studies on therapeutic approaches using saffron and its derivatives for different aspects of $\mathrm{AD}$.

\section{Amyloid- $\beta$, a Key Molecule in AD}

There are three distinct types of amyloid beta including very short oligomers, $A \beta$ derived diffusible ligands, and protofibrils. Amyloid precursor protein (APP) is produced in the brain and is a major source of neurotoxic $A \beta{ }^{60}$ In detail, $\beta$-site APP cleaving enzyme 1 (BACE1), the main $\beta$-secretase in the brain, facilitates APP conversion to $\mathrm{C}_{99}{ }^{61,62}$ Later, $\mathrm{A} \beta$ is generated from $\mathrm{C}_{99}$ by activity of $\gamma$-secretase. The $\gamma$-secretase function is regulated by presenilin 1 and 2 (PSEN1, 2), and any mutation in these proteins leads to excessive production of $A \beta$, initiating the early onset of $\mathrm{AD} .{ }^{63}$ In normal physiological states, there is an equilibrium between the production and clearance of $A \beta$ in the brain, ${ }^{64}$ and any disturbance in $A \beta$ elimination or its overproduction will result in $\mathrm{AD} .{ }^{62}$ Interestingly, 
low amounts of $A \beta$ propitiously contribute to neural development ${ }^{65}$ and can restrain lipoprotein oxidation in cerebrospinal fluid (CSF). ${ }^{66}$ In addition, at low concentrations, $A \beta$ was shown to have neuronal protective effects, ${ }^{67}$ whereas high levels of $A \beta$ lead to neuronal dysfunction by disrupting synaptic function and inducing neurotoxicity through free radical formation. Free radicals are accumulated in cerebral vessels, initiating a condition called cerebral amyloid angiopathy (CAA). CAA is a situation in which the amyloid proteins are placed through cerebral blood vessel walls, ${ }^{68}$ which happens abundantly in $\mathrm{AD} \cdot{ }^{64,69-71}$ Besides, accumulation of $\mathrm{A} \beta$ disrupts $\mathrm{Ca}$ homeostasis in cells and induces excitotoxicity. ${ }^{72}$

Deposition of $A \beta$ also triggers an inflammatory condition through the nuclear factor kappa-light-chain-enhancer of activated $\mathrm{B}$ cell $(\mathrm{Nf}-\kappa \mathrm{B})$ signaling pathway, and activation of microglial cells disrupts central nerves system (CNS) homeostasis in the chronic state. ${ }^{73}$ The soluble form of $A \beta$ is attributed to production of imperative proteins related to memory function (i.e. dendritic spines ${ }^{74}$ ). Soluble $A \beta$ was also shown to have a significant role in $\mathrm{AD}$ induction and progression, and its levels rise in the brain, ${ }^{75}$ blood, and the $\mathrm{CSF}^{76}$ of $\mathrm{AD}$ patients. ${ }^{77}$ Therefore, accumulation or formation of $\mathrm{A} \beta$ plaque is an assessment factor for $\mathrm{AD}$ diagnosis $^{67,78}$ however, there is no known relation between severity of disease and the insoluble form of $A \beta$ or the plaque numbers. $^{78}$

\section{Tau and Neurofibrillary Tangles in AD}

Tau is a protein involved in assembling of tubulin into microtubules ${ }^{79,80}$ able to interact with cytoskeletal proteins actin and spectrin. In physiological conditions, neurons are responsible for tau production; nonetheless, in certain pathologic situations, it is also generated by glial cells. Typically, tau proteins are expressed in the CNS; however, the footprints of their mRNAs were also detected in other tissues. ${ }^{81}$ It seems that tauopathy leads to neural death and NFT formation, which was also correlated with neuronal disturbance and severity of AD. ${ }^{82,83}$ Hyperphosphorylated tau is the main reason behind its neurotoxic properties and also participates in NFT production as a core component. ${ }^{84,85}$

In addition, accumulation of tau is correlated with various degenerative disorders such as $\mathrm{AD}$, progressive supranuclear palsy, argyrophilic grain disease, Pick's disease, Parkinson-dementia complex of Guam, and corticobasal degeneration. ${ }^{86}$ Thus far, NFTs and $A \beta$ are the most important components of AD pathology. Indeed, AD-type NFTs are mostly observed in the brain of old individuals even when there are no A $\beta$ plaques. People with NFTs in the brain share comparable symptoms like AD. Regarding resemblance of Primary age related tauopathy (PART) and AD symptoms, by some definitions, PART is considered as a pre-AD factor or a subtype of $\mathrm{AD} .{ }^{87}$ Despite common features of PART and AD, it has been demonstrated that
PART possesses limited effects on memory and cognition compared to $\mathrm{AD}{ }^{88}$

\section{Apolipoprotein $\mathrm{E}$ and $\mathrm{AD}$}

$A P O E$ is a gene encoding ApoE with 299 amino acids, mainly existing in astrocytes. ApoE regulates lipid homeostasis by modulating lipid transport between different cells and by the action of ApoE receptors in the brain. ${ }^{9}$ Liver and macrophages produce ApoE in peripheral tissue and it plays an important role in cholesterol metabolism. ApoE-4 is reported as a risk factor for various disorders such as atherosclerosis, coronary artery disease, peripheral artery disease, type 2 diabetes, and stroke; such diseases are also correlated with $\mathrm{AD}$ onset. ${ }^{89-92}$

There are three major alleles of the $A P O E$ gene including $\varepsilon 2$, $\varepsilon 3$, and $\varepsilon 4^{10}$ displaying contradictory effects on $A D$ likely due to the difference in amino acid residues 112 and $158 .{ }^{91}$ People carrying $\varepsilon 4$ are more prone to $\mathrm{AD}$ than those carrying $\varepsilon 3$, by far, especially the $\varepsilon 4$ homozygotes. In contrast, $\varepsilon 2$ was shown to reduce $\mathrm{AD}$ risk. ${ }^{93-95}$ According to various genome-wide studies, $\varepsilon 4$ is the key genetic risk factor for AD.96,97 Conversely, some studies refute this statement because some people carrying the $\varepsilon 4$ allele never experience AD. However, they are susceptible to AD twenty times more than others. ${ }^{98}$ It was shown that females and ApoE-4 positive individuals can weakly regulate the interaction between microglia cells and amyloid plaques, leading to greater risk of AD.$^{98}$ In addition, it was reported that aging and $\varepsilon 4$ allele synergistically increase the risk of AD. ${ }^{8,99}$

The findings of human and animal studies demonstrated that ApoEs mediate APP and regulate $A \beta$ aggregation and clearance $(\varepsilon 4>\varepsilon 3>\varepsilon 2)$ via triggering a non-canonical mitogen-activated protein kinase (MAPK) signaling pathway. ${ }^{8,100-102}$ It was stated that absence of ApoE leads to elimination of fibrillar $\mathrm{A} \beta$ deposition in the $A P O E$ gene knockout mouse model. ${ }^{103}$ ApoE- 4 carriers have more senile plaques and experience CAA more frequently than non-carriers, ${ }^{104-106}$ enhancing the risk of $\mathrm{AD} .{ }^{107}$ It was indicated that the presence of the $\varepsilon 4$ allele exacerbated the consequences of sedentary lifestyle and aerobic exercise on cognition in individuals who carry $\varepsilon 4$ in comparison with those not carrying this allele. ${ }^{108-110}$ Smoking tobacco, ${ }^{111-113}$ mild to moderate alcohol consumption, ${ }^{114}$ and diets rich in high saturated fats ${ }^{113}$ have also been shown to be responsible for higher risk of $\mathrm{AD}$ in $\varepsilon 4$ carriers.

\section{Anti-oxidant Effect of Saffron}

The antioxidant properties of Crocus sativus and its constituents were associated with their activities against the oxidative enzymes; glutathione (GSH), glutathione peroxidase (GPx), superoxide dismutase (SOD), ${ }^{23}$ catalase (CAT), ${ }^{115}$ glutathione reductase (GR), and glutathione-S-transferase (GST). ${ }^{116}$ Thus, saffron and its bioactive compounds can modulate oxidative stress in 
cellular organelles and molecules, providing an effective mechanism against neurodegenerative disorders such as AD. It was demonstrated that stressed animals have higher amount of malondialdehyde (MDA), as well as higher activities of GR, GPx, and SOD enzymes in the brain, liver and kidneys, with lower total antioxidant capacity, compared with non-stressed animals. ${ }^{17}$ In stressed groups, the corticosterone level was raised, confirming the point that glucocorticoids are involved in chronicstress-induced oxidative damages, neuronal damage, and impairment of antioxidant defense. ${ }^{118,119}$ Chronically elevated glucocorticoids caused neurogenesis blockade, hippocampal volume loss, and atrophy of dendrites in hippocampal CA3 pyramidal neurons. ${ }^{120,121}$ Clinically, these changes lead to stress-mediated impairments in spatial learning and memory. Treatment with Crocus sativus extract and crocins improved such damages in the stressed group compared with the control group through enhancement of cellular antioxidant and detoxifying pathways. ${ }^{122}$

It was shown that the antioxidant components of saffron, such as crocins, crocetin, safranal, and flavonoids have synergic anti-oxidative effects, as the saffron extract is more efficient than each component alone. ${ }^{123}$ Therefore, saffron and its bioactive compounds suppress oxidative and neuronal damages, and can thus alleviate cognitive deficits. Several studies demonstrated that streptozotocin (STZ) induces brain glucose deprivation and oxidative stress in animal models. Reduced cerebral glucose uptake and energy metabolism results in severe and progressive memory loss and poor learning ability due to deficiency in hippocampal choline acetyltransferase content. ${ }^{12,124}$ Glucose hypo-metabolism and impaired insulin signaling were implicated in early onset and persistent complications in $\mathrm{AD}$. The behavioral alterations of STZ-lesioned rats were attributed to increased MDA, as well as reduced GSH, total thiol, and GPx activity in the brain. ${ }^{125}$

Crocins were shown to improve cognitive performance, restore GPx activity, reduce lipid peroxidation and MDA pool, and replenish total thiol content in STZ-injected mice. ${ }^{125}$ Striatum was chosen for injection due to the fact that it is particularly susceptible to oxidative stress damage due to increasing endogenous levels of antioxidants. Cerebral hypoperfusion leads to excessive reactive oxygen species (ROS) generation, which overwhelms the brain's antioxidant machinery, especially in the cortex and hippocampus. ${ }^{126,127}$ Crocus sativus extract and crocins improved chronic cerebral hypoperfusion-induced cognitive impairments in mice by means of their antioxidative properties. In mice with cerebral ischemiareperfusion injury, safranal treatment significantly restored the hippocampal antioxidant capacity and total$\mathrm{SH}$ content. ${ }^{128}$ Moreover, safranal elevated MDA levels in a dose-dependent style in the rat hippocampus in one animal study which was performed on male NMRI rats and transient global cerebral ischemia model was induced using the four-vessel-occlusion method for $20 \mathrm{~min} .^{23}$ In vitro experiments on neuronally differentiated PC12 cells demonstrated that stress stimuli (i.e. serum/glucose deprivation, hypoxia), triggers cellular oxidative stress events like decline in intercellular levels of GSH and SOD activity. ${ }^{23,128}$ Crocin treatment in PC12 cells attenuated lipid peroxidation and preserved neuron morphology. These effects were correlated to restoration of the activity and expression of SOD, GR, $\gamma$-glutamyl-cysteinyl synthase ( $\gamma$-GCS), and the GSH pool. As mentioned, acrolein activated MAPK/ERK signaling pathway in rat cerebral cortex, as verified by phosphorylation of upstream kinases ERK1/2, c-JNK and p-38, resulting in reduced GSH and an enhancement of MDA content, $A \beta$ deposition, and tau phosphorylation. Co-administration of crocin modulated MAPK signaling pathways, limited MDA pool, reduced $A \beta$ level and tau phosphorylation, and therefore, prevented neuron apoptosis (Figure 1). ${ }^{129,130}$

\section{Inhibition of AChE Activity and Saffron}

It was proven that there is a significant correlation between cholinergic deficiency and cognitive impairments in AD pathogenesis, depending on ACh level in the brain. ${ }^{131}$ Cholinergic pathways encompass the medial forebrain cholinergic nuclei and distribute to the hippocampus, amygdala, and neocortex. AChE hydrolyzes ACh to choline and the acetyl group. AChE inhibitors (AChEIs) prevent this breakdown in the brain. ${ }^{132}$ However, increased $\mathrm{ACh}$ precursors such as choline and lecithin are not useful, but AChEIs have been found to be significantly effective in improving cognitive impairments. Tacrine, donepezil, and rivastigmine are approved $\mathrm{AChEI}$ drugs for $\mathrm{AD}$ treatment, 133-135 while there are many natural products that can act similarly. ${ }^{135}$ Crocins have been shown to inhibit AChE by enhancing ACh levels in synapses and ameliorating cognitive symptoms. ${ }^{128,136}$ In a 22-week, double-blind controlled trial, participants with mild to moderate AD randomly consumed either a $30 \mathrm{mg} / \mathrm{d}$ capsule of saffron or $10 \mathrm{mg} /$ day of donepezil. Data showed the AChE ratio was comparable for both groups, demonstrating that saffron displayed the same therapeutic effect on cognitive function as donepezil. Besides, patients consuming saffron experienced less vomiting, slightly more dry mouth, and hypomania (Figure 1). 5

\section{Inhibition of A $\beta$ Aggregation by Saffron}

It was reported that trans-crocetin decreased $A \beta 42$ aggregation in vitro and increased the level of a key A $\beta 42$ degrading enzyme: the $A \beta 42$-degrading lysosomal protease cathepsin $B(\mathrm{CatB})$. These data indicate $\mathrm{CatB}$ involvement in the degradation pathway of $A \beta 42$ in $A D$. Additionally, the compound modulated the intracellular level of $\mathrm{CatB}$, suggesting a potential mechanism by which the degradation ability of $A \beta 42$ could be retrieved. Studies 


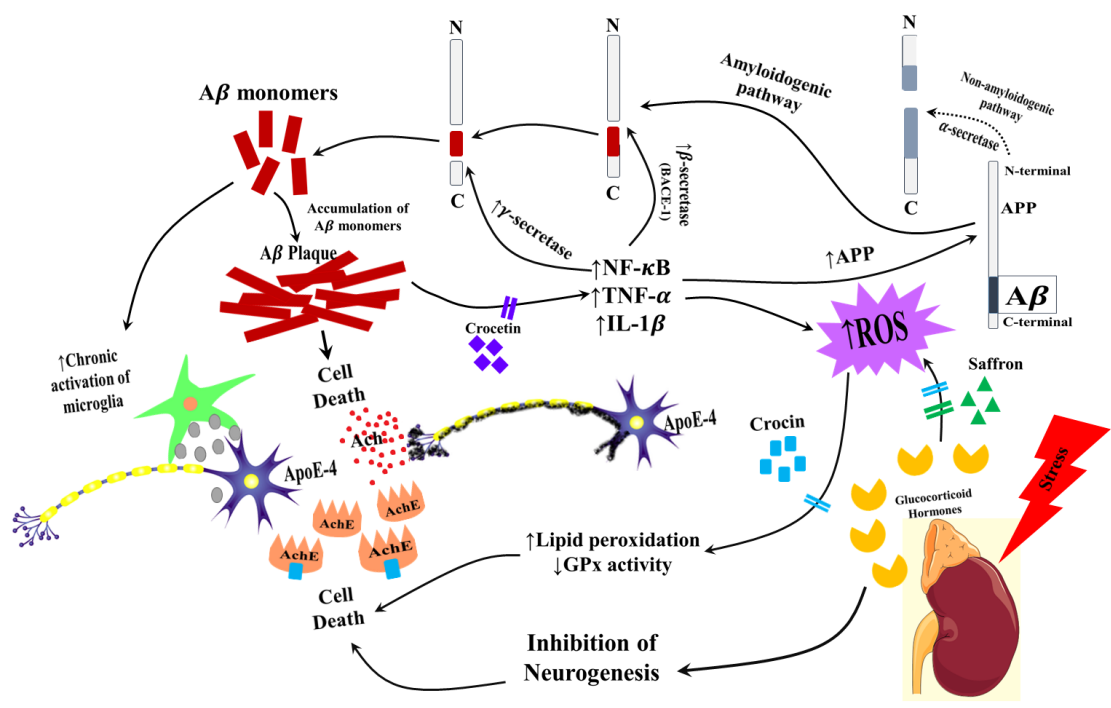

Figure 1. Inhibitory Effect of Saffron and/or its Derivatives in AD. Amyloid precursor protein (APP) is the main source of amyloid $\beta$ plaques in the brain. Crocetin lowered the APP level by decreasing the inflammatory cytokines (IL1 $\beta$, IL18, INF $\gamma$, and TNF $\alpha$ ). Also, safranal and crocin inhibited the ROS formation resulted from increased stress. Crocin has been shown to inhibit acetylcholine esterase (AChE) and enhances the acetylcholine (ACh) in the neuronal synapses which ameliorates the cognitive symptoms.

also revealed that trans-crocetin has a positive effect on A $\beta 42$ clearance and verified its neuroprotective effects on A 442 -induced toxicity in hippocampal-derived cells, resulting in reduced cellular apoptosis. ${ }^{7,137}$ However, it has been shown that crocetin affects multiple signaling pathways involved in neurodegenerative diseases such as extracellular signal-regulated kinase $1 / 2($ ERK-1/2) and caspases. ${ }^{129,137}$ In the rat cerebral cortex, crocin alleviated tau phosphorylation by suppression of ERK and c-Jun $\mathrm{N}$-terminal kinases (JNK) in acrolein induced oxidative stress and amyloid toxicity, showing that modulation of MAPK expression may be a mechanism underlying the crocin neuroprotective characteristic. ${ }^{138}$ Supporting this notion, ERK was shown to mediate $A \beta$-induced tau phosphorylation. ${ }^{139}$ In organotypic hippocampal slice cultures, both crocin and crocetin attenuated LPSinduced hippocampal cell death by decreasing nitric oxide (NO) release from activated microglia, highlighting their neuroprotection abilities. It was also demonstrated that crocin inhibited the $A \beta 42$ formation and aggregation in vitro. ${ }^{140,141}$ In the in vitro neuronal membrane bioreactor model, concomitant administration of crocin and $A \beta$ peptide repressed apoptosis and ROS production dose dependently. ${ }^{142}$ In the in vivo model of $\mathrm{AD}$, the compound inhibited $A \beta$-induced apoptosis through modulating the $\mathrm{Bax} / \mathrm{Bcl}-2$ ratio and cleaved caspase- $3 .{ }^{143}$ In the same manner, crocin prevented neuronal cell death caused by both internal and external apoptotic stimuli in tumor necrosis factor (TNF)- $\alpha$ treated pheochromocytoma PC12 cells via suppression of Bcl-Xs, LICE, and release of cytochrome c from mitochondria. ${ }^{144}$ In another study, pretreatment with safranal reduced $A \beta 42$ induced cell toxicity and apoptosis via MAPK and phosphoinositide 3-kinases (PI3K) pathways in PC12 cells. ${ }^{137}$ In an $A \beta$ induced rat model, application of safranal $(0.025,0.1$, and $0.2 \mathrm{~mL} / \mathrm{kg}$ ) for a week improved cognition deficits, and reduced CA1 neuronal loss and the hippocampal levels of MDA, ROS, protein carbonyl, interleukin $1 \beta$ (IL-1 $\beta)$, IL-6, TNF- $\alpha, \mathrm{Nf}-\kappa \mathrm{B}$, apoptotic biomarkers and DNA fragmentation, glial fibrillary acidic protein (GFAP), myeloperoxidase (MPO), and AChE activity, while enhancing the SOD activity and mitochondrial membrane potential (Figure 1). ${ }^{145}$

\section{Inhibition of A $\beta$-Induced Inflammation by Saffron}

High concentrations of neuroinflammatory cytokines were observed in $\mathrm{AD}$ brains. Aggregation of $\mathrm{A} \beta$ plaques in the brain leads to enhanced neuroinflammatory cytokine levels such as IL-1 $\beta$, IL-18, interferon- $\gamma$ (IFN- $\gamma$ ), and TNF- $\alpha$. This enhancement has been correlated with overproduction of APP in glial cells and upregulation of $\beta$ - and $\gamma$ - secretaseenzymes, which split APP and produce $A \beta .{ }^{146,147}$ Animal studies pointed out that crocetin treatment lowered inflammation, prevented $A \beta$ toxicity and reduced $A \beta$ accumulation by enhancing tightness of the blood brain barrier (BBB), attenuating the increase of NF- $\kappa B$ p65 subunit and $\mathrm{P} 53$ in $\mathrm{AD}$ mice hippocampus. As a result, nitric oxide synthase (iNOS) production increased whereas proinflammatory cytokines such as IL$1 \beta$, IL-18, IFN- $\gamma$, and TNF- $\alpha$ diminished (Figure 1). ${ }^{148}$

\section{Inhibition of tau Phosphorylation by Saffron}

It was shown that corcin inhibited the beta-structure/ random coil ratio of tau protein under fibril state and the aggregation of $1 \mathrm{~N} / 4 \mathrm{R}$ human tau protein in PC12 cells, which was correlated with its chemical structure. It was 
proposed that carbonyl groups of crocin could interact with lysine residues of tau, leading to disruption of fibril formation. ${ }^{149}$ As mentioned, in the rat cerebral cortex, crocin suppressed acrolein induced tau phosphorylation through modulation of ERK and JNK pathways. ${ }^{138}$ Organophosphorus pesticides are accounted as important risk factors of $\mathrm{AD}$. Mohammadzadeh et al reported that crocin $(10,20$ and $40 \mathrm{mg} / \mathrm{kg})$ improved spatial memory deficits in rats through inhibition of postsynaptic density protein 93 (PSD93) gene expression and tau phosphorylation. Besides, crocin significantly alleviated both oxidative and inflammatory parameters such as MDA, TNF- $\alpha$ and IL-6 levels, while increasing GSH in the hippocampus. The compound also reduced the plasma AChE activity and malathion-induced apoptosis in the hippocampus cells. ${ }^{150}$

\section{Saffron and ApoE Related Approaches}

Transcriptions of ApoE and ABCA1 are regulated via the linkage of peroxisome proliferator activated receptor $\gamma$ (PPAR $\gamma$ ) and liver $\mathrm{X}$ receptor (LXRs) to the retinoid $\mathrm{X}$ receptor (RXR). ${ }^{151}$ It was shown that deletion of ABCA1 led to an increase in $A \beta$ deposition in the murine brain, especially in ApoE-4 carriers, signifying its function in $\mathrm{A} \beta$ clearance. ${ }^{152} \mathrm{ABCA} 1$ regulates the ApoE lipidation by means of cholesterol efflux to ApoE and adjusts the ApoE level. On the other hand, binding of ApoE to $A \beta$ changes the conformation of $A \beta$ and increases its clearance. ${ }^{153}$ In the Batarseh study, administration of saffron extract enhanced ABCA1 and PPAR $\gamma$ expression in murine brain, which led to $A \beta$ degradation and deposition by modulating the BBB clearance and upregulation of ApoE-dependent A $\beta$ clearance pathway (Figure 1). ${ }^{148}$

\section{Clinical Trials on Saffron and AD}

The mechanism of action of saffron in AD treatment and clinical trials is still under investigation. As previously mentioned, saffron showed similar efficacy as donepezil on patients with mild to moderate $\mathrm{AD}$ after 22 weeks by exploiting clinical assessment methods; the Alzheimer's Disease Assessment Scale-cognitive subscale (ADAS-cog) and Clinical Dementia Rating Scale-Sums of Boxes (CDRSB). ${ }^{154}$ Memantine is another approved drug for AD treatment, known to block the glutamatergic N-MethylD-aspartic acid (NMDA) receptors and their mediated excitotoxicity in the brain. Administration of saffron at low dose $(30 \mathrm{mg} / \mathrm{kg})$ resulted in the same outcomes as Memantine in moderate to severe AD patients. The Severe Cognitive Impairment Rating Scale (SCIRS) scores for both groups indicated no significant difference in the baseline and the final outcomes of the therapy. ${ }^{155}$ Furthermore, the results of 16 weeks of saffron therapy versus placebo in individuals with mild to moderate $\mathrm{AD}$ were in line with the aforementioned clinical trials. Indeed, saffron significantly prevented cognitive impairments compared to placebo, highlighting the hypothesis that saffron is beneficial to people suffering from $\mathrm{AD}$ and memory deterioration. ${ }^{156}$ Administration of saffron with standardized herbal medicine formula named sailuotong, containing Panax ginseng and Gingko biloba, showed potential effectiveness in improving working memory in comparison with placebo in healthy adults. ${ }^{157}$ Concomitantly, application of saffron at a dose of $125 \mathrm{mg} / \mathrm{d}$ for a year enhanced cognitive function compared with the control group, suggesting that saffron may be an alternative medicine for $\mathrm{AD}$ drugs. ${ }^{158}$ In a single blind randomized trial, 17 patients diagnosed with amnesic and multi domain mild cognitive impairment (aMCImd) were treated with saffron over a year. Neuropsychological assessment included a battery of psychometric tests assessing mood, activities of daily life, behavior, magnetic resonance imaging (MRI) 3T, and general cognitive function, while some patients were assessed via 256-channel electroencephalogram (HDEEG). The findings of the study showed that saffron improved the MMSE scores, while amending the MRI, EEG, and event-related potential (ERP) in latency of P300 domain, suggesting that saffron may be a choice for MCI therapy (Table 1$).{ }^{158}$

\section{In Vivo Interventions of Saffron and $\mathrm{AD}$}

Regarding the potential role of oxidative stress in pathogenesis of $\mathrm{AD}$ and other neurodegenerative diseases, the efficacy of saffron extract was investigated in BALB/c mice hippocampus cells with neuronal damage induced by $\mathrm{D}$-galactose and sodium nitrite $\left(\mathrm{NaNO}_{2}\right)$. While D-galactose increased free radicals and $\mathrm{NaNO}_{2}$ caused hypoxia, saffron inhibited the neurotoxicity resulting from their actions. This investigation suggested that in addition to anti-oxidative actions, saffron can also increase cerebral blood flow. ${ }^{159}$ Administration of crocin in ddY mice after brain infarction induced by occlusion of a middle cerebral artery led to significant reduction of the infarcted area via passing the BBB. Interestingly, crocin was effective in a dose ten-fold less than $\alpha$-tocopherol. ${ }^{160}$ Similarly, $8 \mathrm{mg} /$ $\mathrm{kg}$ crocetin reversed memory derangement in the vascular dementia model in rats including cortical and hippocampal hypoperfusion through permanent occlusion of common carotids, which has been confirmed in histopathological analysis. ${ }^{161}$ In accordance, Hosseinzadeh et a ${ }^{162}$ found that crocin $(25 \mathrm{mg} / \mathrm{kg})$ and saffron $(250 \mathrm{mg} / \mathrm{kg})$ attenuated memory deficits via decreasing oxidative stress in Wistar rats.

Zheng et al reported that following cerebral ischemia in $\mathrm{C} 57 \mathrm{BL} / 6 \mathrm{~J}$ mice, pre-treatment with crocin and saffron inhibited oxidative stress parameters such as MDA and NO, while it enhanced the GPx, SOD, and iNOS activities. In addition, other oxidative markers, phosphorylation of ERK1/2, and the expression of membrane G proteincoupled receptor kinase 2 (GRK2) was reduced. The structure of cortical microvascular endothelial cells was 
preserved by crocin. ${ }^{163}$

In a similar manner, pre-treatment with crocin and saffron in rats modulated the CAT and Na-K ATPase activities as well as aspartate and glutamate levels. ${ }^{40}$ Increased lipid peroxidation is known as a marker of oxidative stress and IP exposure of saffron extract in Wistar rats led to lipid peroxidation reduction and amelioration of mitochondrial function in synaptosomal fractions, which were predisposed to the neurotoxin mitochondrial toxin 3-nitropropionic (3-NPA). ${ }^{126}$ IP and intrahippocampal administration of crocin significantly improved the indicators of spatial memory. In Wistar rats, application of crocin reduced the $\mathrm{Bax} / \mathrm{Bcl}-2$ ratio and apoptosis, while the ratio of autophagy markers Beclin-1 and LC3-II/ LC3-I remained unchanged. ${ }^{143}$

Moreover, administration of crocin improved sporadic $\mathrm{AD}$ induced by STZ in Wistar rats. According to the result of the Passive Avoidance Test and Maze Task Performance, memory and learning deficits were attenuated in the crocin group. ${ }^{164-166}$ From a molecular viewpoint, crocin decreased MDA levels while elevating the total thiol level and the GPx activity in contrast to STZ. ${ }^{165}$ Likewise, pretreatment with NCSe (combination of Nardostachys jatamansi, crocetin and selenium) in Wistar rats attenuated STZ-elicited oxidative stress by reducing thiobarbituric acid reactive substance level and increasing the glutathione, GPx, GST, and CAT activities, resulting in better performance in passive avoidance test and Morris water maze. Notably, this study mentioned that a multi-substance approach can be more potent than singular therapy. ${ }^{167}$ Pretreatment of Wistar rats with saffron extract or crocin for 21 days before predisposition to chronic stress showed a significant neuroprotective effect on the hippocampus and an escalation in anti-oxidative stress markers, ${ }^{168,169}$ as well as the mRNA expressions of CAT and SOD. ${ }^{170}$ In another study, pre-treatment with a low dose of saffron prevented learning deficits induced by scopolamine in Wistar rats whereas post-treatment with saffron extract significantly retrieved data storage and recognition memory. ${ }^{171,172}$ These data are against with findings by Zhang et al. ${ }^{173}$

It has been reported that saffron extract modified morphine-induced memory deficits in mice, ${ }^{47}$ which is in line with the study by Haghighizad et al which indicated the efficacy of saffron extract on improving morphineinduced spatial learning and memory deficit in rats. Other investigations achieved the same results in ethanol-induced memory deficits in Std-ddY mice. ${ }^{174}$

Moreover, administration of $15-30 \mathrm{mg} / \mathrm{kg}$ crocin in Wistar rats reduced ketamine (non-competitive NMDA receptor antagonist) induced memory impairments using the novel object recognition task. ${ }^{48}$ Saffron extract attenuated the acetaldehyde-induced inhibition of

Table 1. Saffron and its Derivatives; Clinical Interventions in AD (Human Study)

\begin{tabular}{|c|c|c|c|c|c|c|c|c|c|}
\hline \multirow{2}{*}{ Study Design } & \multirow{2}{*}{$\begin{array}{l}\text { Study } \\
\text { Assessment }\end{array}$} & \multicolumn{2}{|c|}{ Intervention } & \multicolumn{2}{|c|}{ Number of Patients } & \multirow{2}{*}{$\begin{array}{l}\text { Treatment } \\
\text { Duration }\end{array}$} & \multirow{2}{*}{ Outcomes } & \multirow{2}{*}{ Adverse Effects } & \multirow{2}{*}{ Ref } \\
\hline & & Case & Control & Case & Control & & & & \\
\hline $\begin{array}{l}\text { Mild to } \\
\text { moderate AD }\end{array}$ & $\begin{array}{l}\text { MMSEADAS- } \\
\operatorname{cog}, \text { CDR-SB }\end{array}$ & $\begin{array}{l}\text { SE (15 mg twice/ } \\
\text { day), oral }\end{array}$ & $\begin{array}{l}\text { donepezil } \\
\text { (5 mg } \\
\text { twice/ } \\
\text { day) }\end{array}$ & $\mathrm{n}=24$ & $\mathrm{n}=23$ & 22 weeks & Effective as donepezil & $\begin{array}{l}\text { Dizziness, dry mouth, } \\
\text { fatigue, hypomania, } \\
\text { nausea (adverse effects } \\
\text { were similar in both } \\
\text { treatment \& control } \\
\text { groups, except vomiting) }\end{array}$ & 154 \\
\hline $\begin{array}{l}\text { Mild } \\
\text { cognitive } \\
\text { impairment }\end{array}$ & MMSE & $\begin{array}{l}\text { SE }(125 \mathrm{mg} / \mathrm{d}), \\
\text { oral }\end{array}$ & - & $\mathrm{n}=17$ & $\mathrm{n}=18$ & 12 months & $\begin{array}{c}\text { Improvement of } \\
\text { cognitive dysfunction }\end{array}$ & - & 158 \\
\hline $\begin{array}{l}\text { Healthy } \\
\text { adults }\end{array}$ & $\begin{array}{l}\text { Cognitive test } \\
\text { scores, oddball } \\
\text { task -ERP }\end{array}$ & $\begin{array}{l}\text { Sailuotong (Panax } \\
\text { ginseng, Ginkgo } \\
\text { biloba \& Crocus } \\
\text { sativus) } \\
\text { (120 mg/d) }\end{array}$ & Placebo & $\mathrm{n}=8$ & $\mathrm{n}=8$ & 1 week & $\begin{array}{l}\text { Increase of Sailuotong } \\
\text { in alphabetic working } \\
\text { memory \& visual } \\
\text { working memory }\end{array}$ & - & 157 \\
\hline $\begin{array}{l}\text { Mild to } \\
\text { moderate AD }\end{array}$ & $\begin{array}{l}\text { MMSEADAS- } \\
\text { cog, CDR-SB }\end{array}$ & $\begin{array}{c}\text { SE } \\
(15 \mathrm{mg} \text { twice/day) }\end{array}$ & Placebo & $\mathrm{n}=22$ & $\mathrm{n}=20$ & 16 weeks & $\begin{array}{l}\text { Improvement of } \\
\text { cognitive function }\end{array}$ & $\begin{array}{l}\text { Dizziness, dry mouth, } \\
\text { fatigue, hypomania, } \\
\text { nausea (adverse effects } \\
\text { were similar in both } \\
\text { treatment \& control } \\
\text { groups) }\end{array}$ & 156 \\
\hline $\begin{array}{l}\text { Moderate to } \\
\text { severe AD }\end{array}$ & MMSE & SE $(30 \mathrm{mg} / \mathrm{d})$ & $\begin{array}{l}\text { Memantin } \\
(20 \mathrm{mg} / \mathrm{d})\end{array}$ & $\mathrm{n}=30$ & $\mathrm{n}=30$ & 12 months & $\begin{array}{l}\text { Effective as Memantin } \\
\text { in reducing cognitive } \\
\text { decline }\end{array}$ & $\begin{array}{l}\text { Nausea, vomiting, dry } \\
\text { mouth, fatigue, dizziness, } \\
\text { confusion, agitation, } \\
\text { sedation (adverse effects } \\
\text { were similar in both } \\
\text { treatment \& control } \\
\text { groups) }\end{array}$ & 155 \\
\hline
\end{tabular}

SE, saffron extract; MMSE, Mini-mental state examination; ADAS-cog, Alzheimer's disease assessment scale-cognitive subscale; CDR-SB, Clinical dementia rating scale-sums of boxes; ERP, event-related potential; MRI, magnetic resonance imaging. 
hippocampal long-term potentiation in Wistar rats. ${ }^{175}$

For in vivo studies, one of the best proficient models of $\mathrm{AD}$ can be imitated by chronic administration of aluminum due to the same neurotoxic pathological changes in the brain. ${ }^{176-179} \mathrm{Al}$ accumulation in the brain leads to oxidative stress in the hippocampus and the cerebral cortex including lipid peroxidation, and deterioration of endogenous antioxidant enzymes, protein kinases, and $\mathrm{Na}^{+}-\mathrm{K}^{+}$ATPase in the cell membrane. ${ }^{180-182}$ It was shown that short-term co-administration of saffron extract with $\mathrm{Al}$ alleviated the oxidative stress markers and the monoamine oxidase activity; however, there was no effect on cognitive function and memory capacity in BALB/c mice. ${ }^{41}$ Oral administration of $100 \mathrm{mg} / \mathrm{kg}$ saffron extract reversed the arsenic neurotoxicity while it promoted cognitive and memory functions. This was accompanied by decreasing glutamate and aspartate levels in cortical and hippocampal areas in Wistar rats. ${ }^{46}$

Various parts of the human body are affected by aging which ultimately results in dementia and progressive brain dysfunction. Oxidative stress in lipids, proteins and nucleic acids ${ }^{183-185}$ along with poor performance of the cholinergic system due to reduced AChE activity in different parts of the cerebrum ${ }^{49}$ and synaptic plasma membranes ${ }^{186}$ is the basis for the main hypothesis for memory impairment in aged humans and rodents. In the study by Papandrou et al, crocetin decreased lipid peroxidation and caspase 3 activity in both adult and aged mice although the AChE activity was reduced in only adult BALB/c mice, emphasizing the greater role of oxidative stress in cognitive dysfunction compared to the cholinergic system (Table 2). ${ }^{136}$

\section{In Vitro Interventions of Saffron and $\mathrm{AD}$}

In vitro administration of safranal, crocetin, and dimethylcrocetin inhibited $\mathrm{ds}$ and preserved the SOD activity which were exposed to serum/glucose deprivation. Moreover, crocin suppressed the caspase-8 (an initiator caspase) activity and increased the survival time of neuronal cells. It was indicated that the anti-oxidative ability of crocin was more than $\alpha$-tocopherol (a form of vitamin E) at the same dosage. ${ }^{188}$ Comparison of different saffron carotenoids revealed that $10 \mu \mathrm{M}$ crocin is more potent than tricrocin and dicrocin in terms of reducing the GSH and caspase 3 activities in PC12 cells. ${ }^{160}$

Saffron and crocetin showed neuroprotective effects on $\mathrm{H}_{2} \mathrm{O}_{2}$ induced toxicity in human neuroblastoma $\mathrm{SH}$ SY5Y cells by diminishing ROS products and caspase 3 activity. ${ }^{136}$ Pretreatment of PC12 with $10-50 \mu \mathrm{g}$ crocin in the neurotoxic state, induced by acrylamide, reinforced the neuroprotective effect of this compound. Indeed, crocin suppressed intracellular ROS production and apoptosis in these cells. ${ }^{189}$ The same neuroprotective action of crocin was recorded in PC12 cells toxicated by either glucose or high levels of ROS. ${ }^{190}$ In crocin pre-treated neurotoxic PC12 cells, the ratio of Bax/Bcl2 decreased due to the apoptosis inhibitory effect of this compound. ${ }^{189,191,192}$ Crocin downregulated TNF- $\alpha$ receptor activity in PC12 cells (mainly through the suppression of $\mathrm{Bcl}-2$ mRNA expression) and increased caspase 3 activity. Besides, crocin prevented intracellular ROS formation elicited by daunorubicin. ${ }^{144}$ In another study, $10 \mu \mathrm{M}$ of crocin significantly restored ethanol induced NMDA receptor dysfunction and improved memory impairment in hippocampal slices of male Wistar rats. ${ }^{45}$ Crocin suppressed 1-methyl-4- phenylpyridiniuminduced endoplasmic reticulum stress and mitochondrial dysfunction in PC12 cells. ${ }^{193}$ It is well established that microglial cells play pivotal roles in CNS homeostasis, but chronic activation of microglial cells predisposes neuronal cells to the inflammatory state by producing inflammatory cytokines including IL6, IL $1 \beta$, TNF- $\alpha$, and $\mathrm{Nf}-\kappa \mathrm{B}$ transcriptional activity as well as $\mathrm{NO}$ release. It was shown that saffron extract repressed the expressions of these elements in BV2 mouse brain microglial cells. ${ }^{194}$ Overall, the neuroprotective features of crocin are mainly attributed to reduction of pro-inflammatory cytokines and neurotoxic factors (Table 3). ${ }^{187,194}$

\section{Safety}

Animal Studies

Considering the worldwide application of saffron, monitoring the probable adverse effects of this plant and its bioactive components seems necessary. Acute oral application of saffron in mice and rats was shown to be safe. Following IP administration in mice, the 50\% lethal dose $\left(\mathrm{LD}_{50}\right)$ for saffron was reported as $1.6 \mathrm{~g} / \mathrm{kg}$, while for oral intake, $\mathrm{LD}_{50}$ was $4120 \pm 556 \mathrm{mg} / \mathrm{kg} .{ }^{195}$ Administration of $3 \mathrm{~g} / \mathrm{kg}$ crocin (IP and PO) for two days did not cause any mortality in mice; therefore, it was deduced that crocin is the safest substance of saffron. ${ }^{196}$ Safranal exhibited $\mathrm{LD}_{50}$ values of $0.75 \mathrm{~mL} / \mathrm{kg}$ and $3.5 \mathrm{~mL} / \mathrm{kg}$ for IP and oral administration in male Wistar rats, respectively. ${ }^{196}$ In rats, sub-acute IP exposure to saffron ethanolic extract decreased body weight, red blood cell (RBC) count, hemoglobin $(\mathrm{Hb})$, and hematocrit $(\mathrm{Hct})$. Conversely in a dose-dependent manner, white blood cells (WBC), alanine aminotransferase (ALT), aspartate aminotransferase (AST) enzymes, serum urea, uric acid, and creatinine $(\mathrm{Cr})$ levels increased. Pathological findings represented some mild to moderate liver and renal damage. ${ }^{197}$

Evaluation of saffron regarding spermatogenesis index in rats showed oral administration of $200 \mathrm{mg} / \mathrm{kg}$ saffron for 28 days reduced tubular differentiation index, spermatogenesis index, and repopulation index. ${ }^{198}$ Another in vivo study demonstrated that crocin $(90 \mathrm{mg} / \mathrm{kg})$ for 21 days increased the low-density lipoprotein (LDL) level, while decreasing alkaline phosphatase (ALP) and albumin levels, without serious injuries in main organs even after 


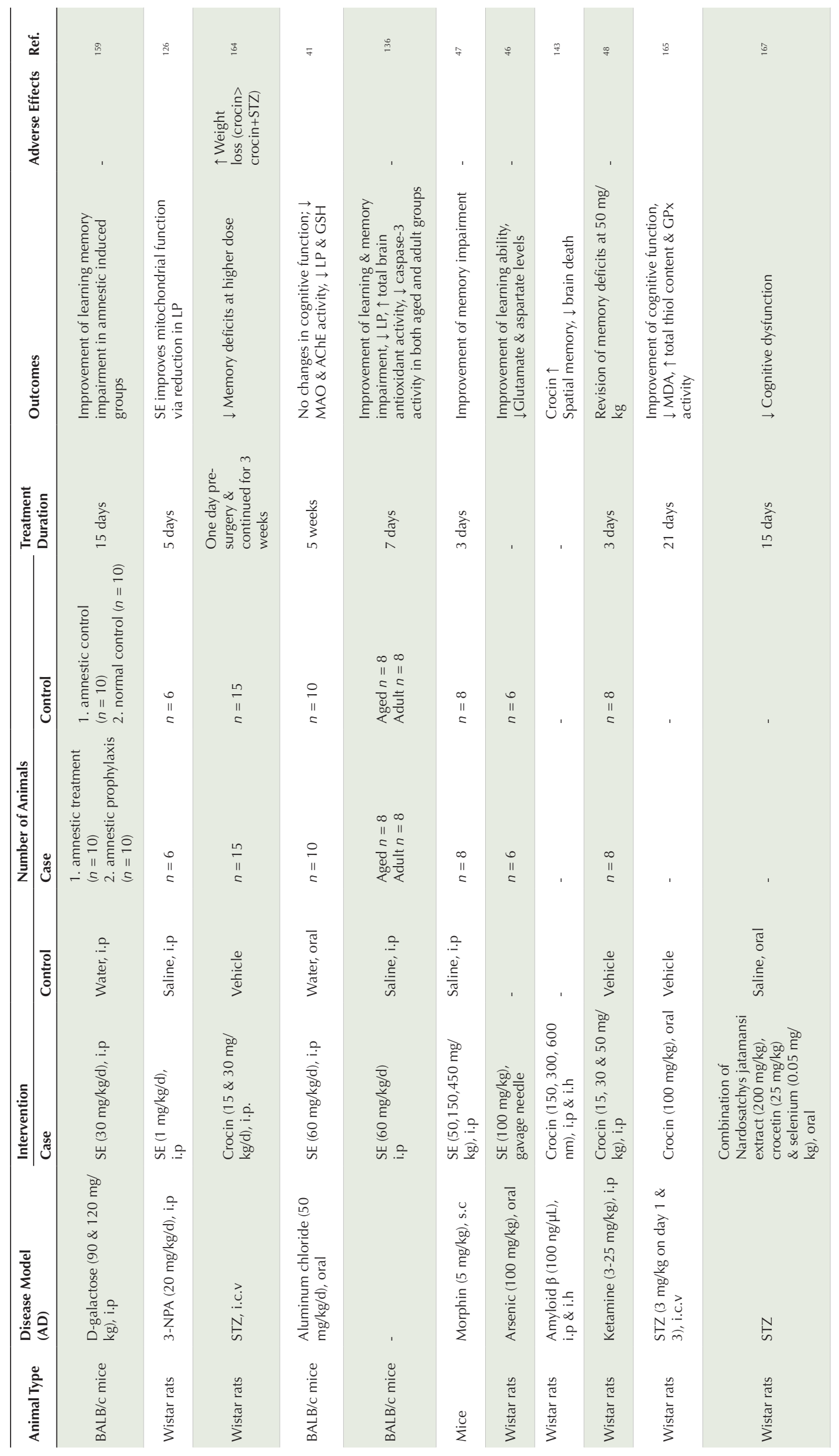




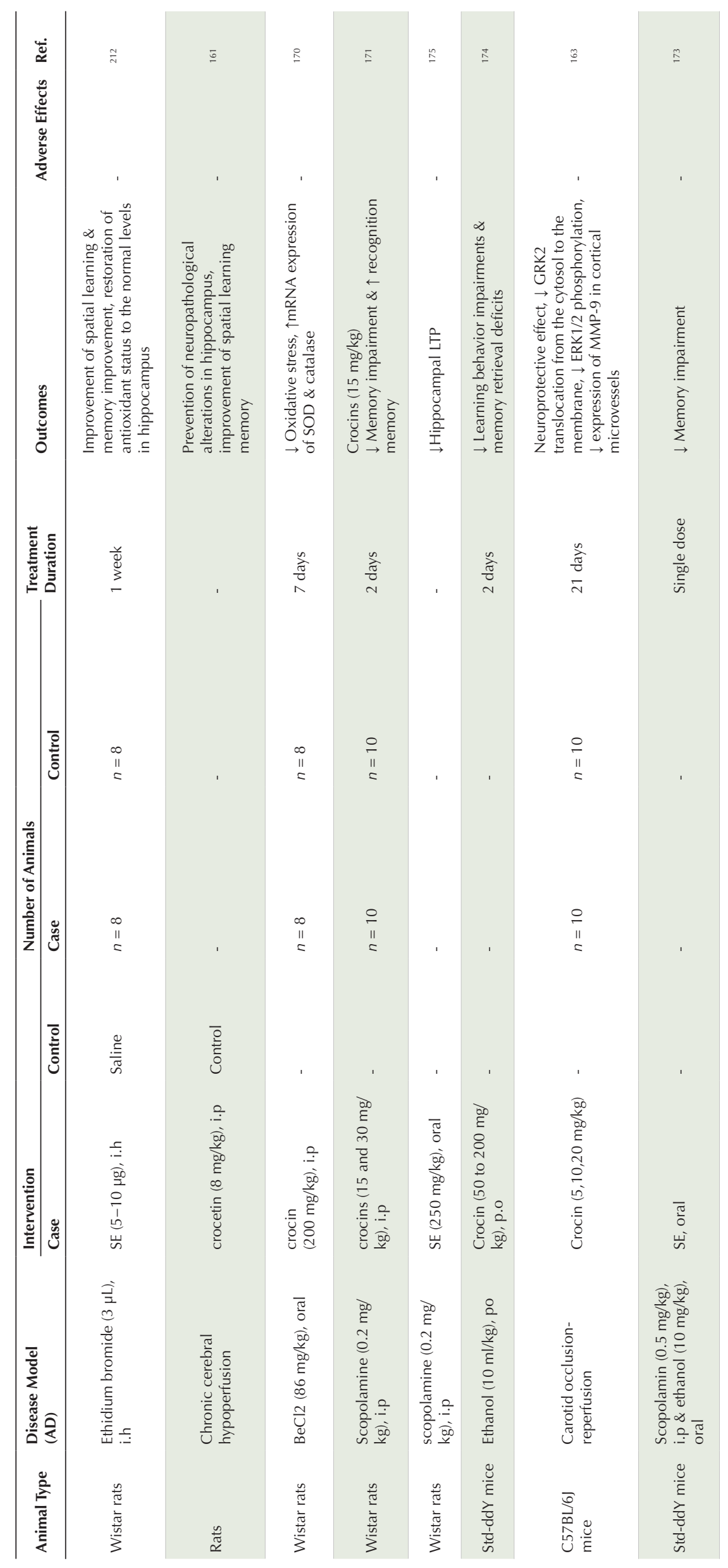




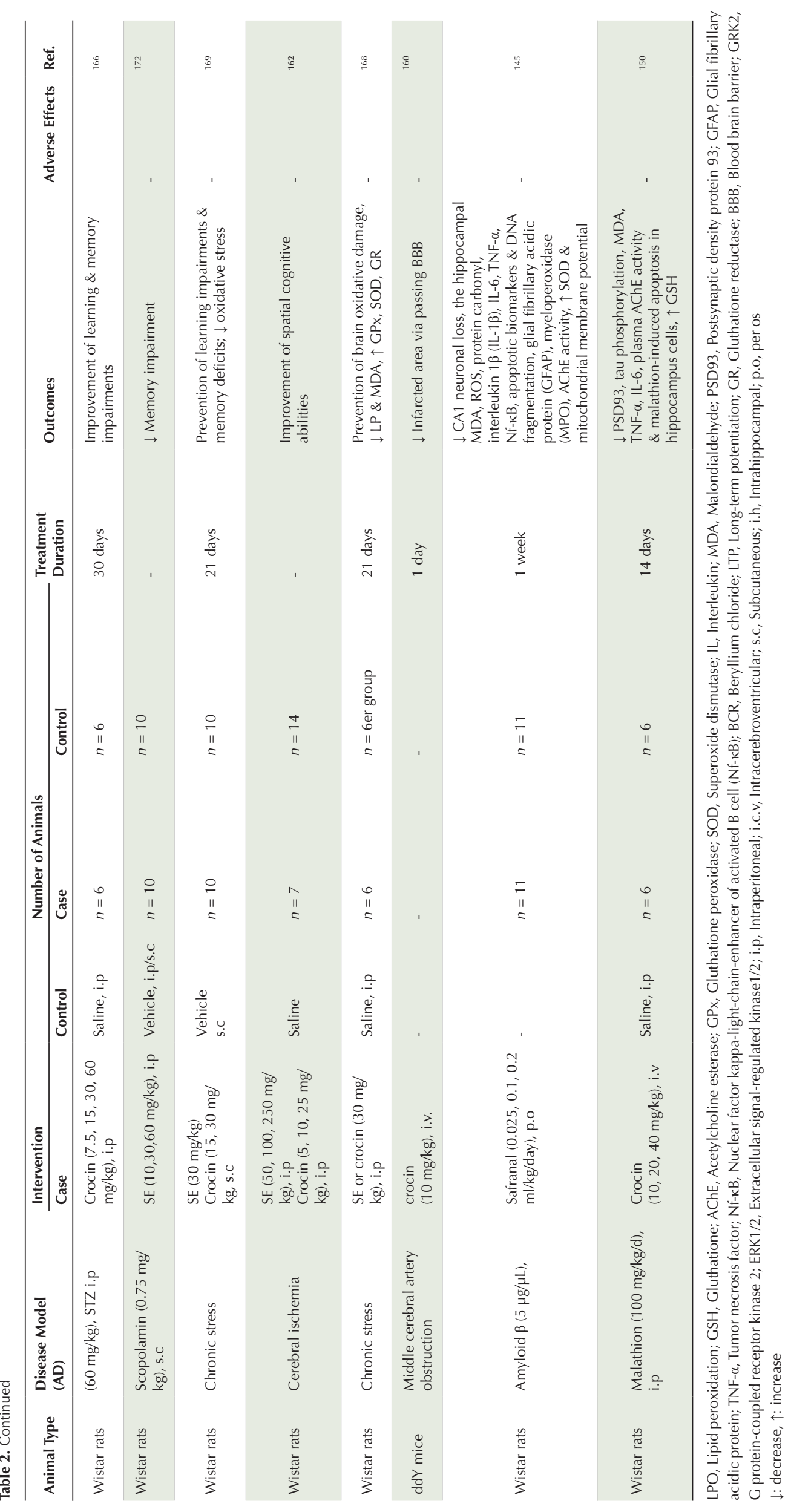




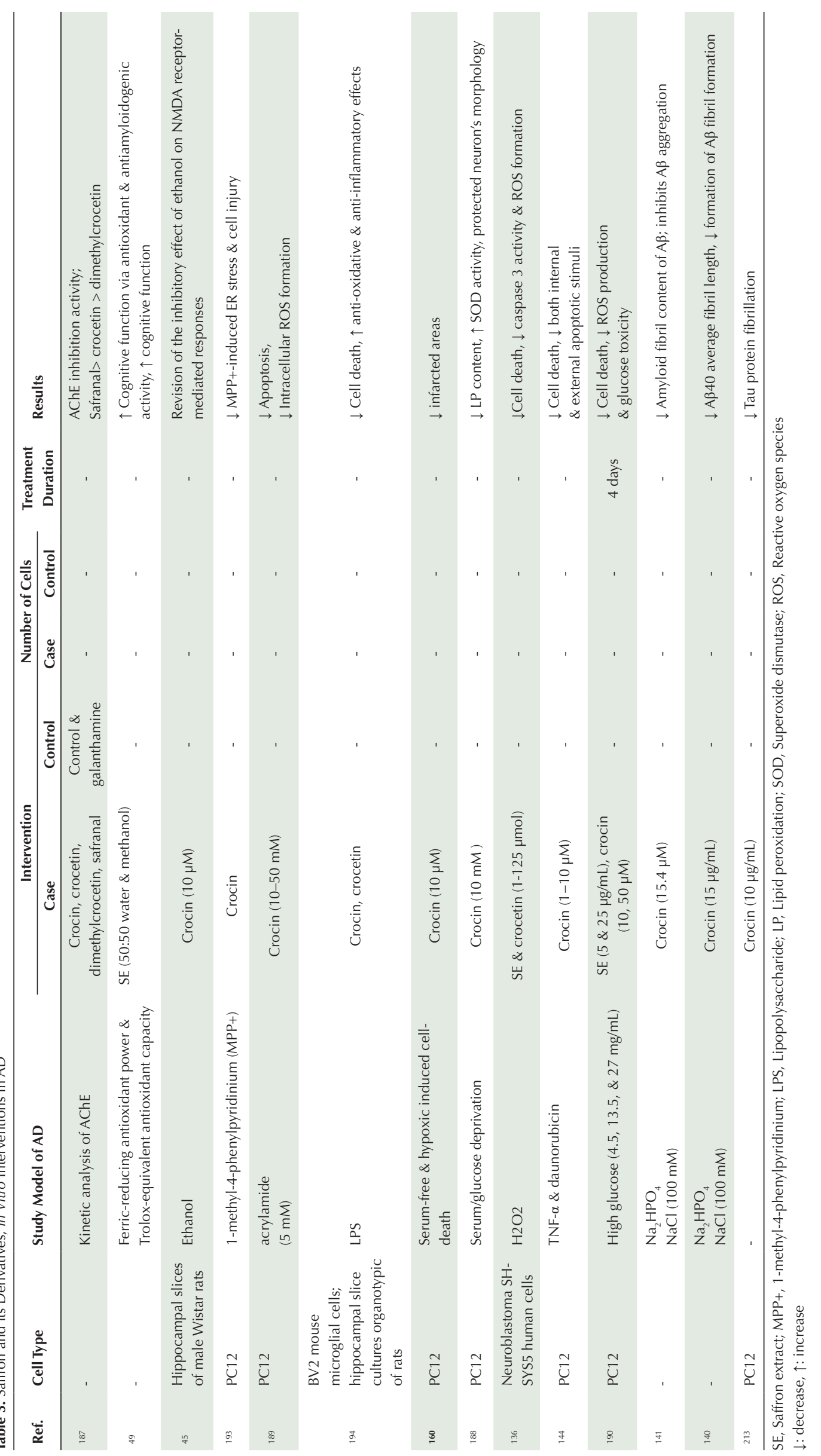


exposure to $180 \mathrm{mg} / \mathrm{kg}$ of crocin. ${ }^{196}$ This was in line with results of a study by Taheri et al since IP administration of crocin at concentrations of 50,100 and $200 \mathrm{mg} / \mathrm{kg}$ once a week for four weeks caused no elevation in Cr, ALT, AST, ALP, uric acid and urea levels in rats. Pathological examination revealed no significant hepatic toxicity. ${ }^{199}$

Three weeks of safranal oral administration $(0.1,0.25,0.5$ $\mathrm{mL} / \mathrm{kg}$ ) in rats, led to reduction of triglyceride, cholesterol, ALP, RBC count, platelet count, $\mathrm{Hb}$, and Hct, while the level of blood urea nitrogen (BUN) increased. However, no pathological lesion in organs (liver, spleen and heart) or toxicity effect on the cellular and humoral immune system were detected. ${ }^{200}$ Oral administration of 4000 and 5000 $\mathrm{mg} / \mathrm{kg}$ saffron in BALB/c mice for 5 weeks demonstrated that sub-chronic exposure to saffron decreased the RBC and WBC counts and increased BUN and Cr, indicating renal dysfunction. ${ }^{201}$ Worth mentioning, usually in animal studies, saffron is used at high doses although it exhibited protective effects in lower doses. ${ }^{202}$

\section{Human Studies}

Like other plant extracts, several side effects were reported for saffron such as nausea, vomiting, anxiety, headache, dizziness, epistaxis, bloody diarrhea, and numbness. It was assumed that at doses of 12-20 g, saffron can be fatal. ${ }^{203}$

In a clinical study on healthy volunteers, standing systolic blood pressure and mean arterial pressure were reduced by receiving saffron tablets $(400 \mathrm{mg}$ ); however, there was no change at a dose of $200 \mathrm{mg} .{ }^{204}$ In another study, hematologic factors and the coagulation system were not disturbed by saffron tablets (200 and 400 $\mathrm{mg}){ }^{205}$ Safety of crocin was investigated in a doubleblind, placebo-controlled trial in which healthy volunteers received crocin tablets $(20 \mathrm{mg})$ for a month. Crocin tablets decreased amylase, partial thromboplastin time, and the WBC count, demonstrating that crocin was relatively safe. ${ }^{206}$ Pregnant women with fetuses at gestational ages between the first and twentieth weeks were susceptible to abortion if they received saffron at high doses. ${ }^{207}$ In addition, uterine contractions induced by saffron have been suggested as a mechanism for abortion. ${ }^{204,208,209}$ At the beginning of the active phase of labor, administration of saffron capsules $(250 \mathrm{mg})$ reduced mean anxiety score and mean fatigue score, ${ }^{210}$ while saffron capsules in the active phase of labor reduced pain. The infant and mother did not show any toxicity in the saffron group compared with controls. ${ }^{211}$

Based on the findings of animal studies ( $\mathrm{LD}_{50}$ values), crocin might be the safest component of saffron, and no significant damage has been mentioned for this compound at pharmacological dosage. At high concentrations, saffron and its constituents showed some developmental toxicity on animal infants. Exposure to high levels of saffron was shown to increase miscarriage rates in pregnant women, suggesting avoidance of high doses during pregnancy. ${ }^{202}$

\section{Conclusion and Future Perspectives}

Statistics confirm that $\mathrm{AD}$ remains a global growing health concern. A wide range of natural and synthetic molecules have been studied for their ability to either prevent or counteract $\mathrm{AD}$ initiation, progression, and complications. The findings of this study indicate that saffron and/ or its components target various regulatory molecules involved in $\mathrm{AD}$. Regarding its pleotropic effects on the nervous system, including anti-amyloid, anti-AChE, anti-inflammatory, and anti-oxidant features, along with its inhibitory effect on tau hyper-phosphorylation, and upregulation of ApoE activity, it seems that saffron could find its niche in $\mathrm{AD}$ therapy with substantial potential as a therapeutic nutraceutical with the advantage of low toxicity and easy accessibility. Further studies, particularly clinical trials, are now required to determine whether saffron and its bioactive phytochemicals may be suitable for $\mathrm{AD}$ or other neurodegenerative disorders. Other clinical trials are warranted to examine the safety and efficacy of various doses of the plant and improved formulations with better pharmacokinetics and bioavailability are needed. Several reports have raised questions about the safety and efficacy of saffron or its derivatives, especially at high doses, whereas some studies have shown no adverse effects. It is suggested that the mode of administration and the duration of saffron therapy are also critical factors that can significantly affect the efficacy of AD treatment. Since saffron is a part of daily diets in many Asian countries and seems non-toxic, it is obligatory to investigate whether dietary supplementation with saffron may be a beneficial preventive or slowing nutritional strategy for neurological disorders. ${ }^{212}$

\section{Authors' Contribution}

NZ, BP, NMR and NAL: collection and/or assembly of data and interpretation, manuscript writing; $\mathrm{SM}, \mathrm{VJ}, \mathrm{AHA}$ and $\mathrm{SA}$ : provision of study material, conception and design, and final approval of manuscript. All the authors have read and approved the manuscript.

\section{Conflict of Interest Disclosures}

None.

\section{Ethical Statement}

Not applicable.

\section{References}

1. Bhardwaj D, Mitra C, Narasimhulu CA, Riad A, Doomra M, Parthasarathy S. Alzheimer's Disease-Current Status and Future Directions. J Med Food. 2017;20(12):1141-51. doi: 10.1089/jmf.2017.0093.

2. Brookmeyer R, Johnson E, Ziegler-Graham K, Arrighi HM. Forecasting the global burden of Alzheimer's disease. Alzheimers Dement. 2007;3(3):186-91. doi: 10.1016/j. jalz.2007.04.381

3. Tsuno N. Donepezil in the treatment of patients with Alzheimer's disease. Expert Rev Neurother. 2009;9(5):591-8. doi: 10.1586/ern.09.23.

4. Mohamed T, Shakeri A, Rao PP. Amyloid cascade in Alzheimer's disease: recent advances in medicinal chemistry. Eur J Med Chem. 2016;113:258-72. doi: 10.1016/j. ejmech.2016.02.049. 
5. Adalier N, Parker H. Vitamin E, turmeric and saffron in treatment of Alzheimer's disease. Antioxidants (Basel). 2016;5(4):40. doi: 10.3390/antiox5040040.

6. Swerdlow RH, Burns JM, Khan SM. The Alzheimer's disease mitochondrial cascade hypothesis: progress and perspectives. Biochim Biophys Acta. 2014;1842(8):1219-31. doi: 10.1016/j. bbadis.2013.09.010

7. Barage SH, Sonawane KD. Amyloid cascade hypothesis: Pathogenesis and therapeutic strategies in Alzheimer's disease. Neuropeptides. 2015;52:1-18. doi: 10.1016/j. npep.2015.06.008.

8. Reiman EM, Chen K, Liu X, Bandy D, Yu M, LeeW, et al. Fibrillar amyloid- $\boldsymbol{\beta}$ burden in cognitively normal people at 3 levels of genetic risk for Alzheimer's disease. Proc Natl Acad Sci U S A. 2009;106(16):6820-5.doi:10.1073/pnas.0900345106.

9. Mahley RW, Weisgraber KH, Huang Y. Apolipoprotein E4: a causative factor and therapeutic target in neuropathology, including Alzheimer's disease. Proc Natl Acad Sci U S A. 2006;103(15):5644-51. doi: 10.1073/pnas.0600549103.

10. Nussbaum RL, Mclnnes RR, Willard HF. Thompson \& Thompson genetics in medicine e-book. Elsevier Health Sciences; 2015.

11. BirdTD.Alzheimer disease overview. GeneReviews $®$ [Internet]: University of Washington, Seattle; 2018.

12. Naghizadeh B, Mansouri MT, Ghorbanzadeh B. Protective effects of crocin against streptozotocin-induced oxidative damage in rat striatum. Acta Med Iran. 2014;52(2):101-5.

13. Karch CM, Cruchaga C, Goate AM. Alzheimer's disease genetics: from the bench to the clinic. Neuron. 2014;83(1):1126. doi: 10.1016/j.neuron.2014.05.041.

14. Heneka MT, Carson MJ, El Khoury J, Landreth GE, Brosseron F, Feinstein DL, et al. Neuroinflammation in Alzheimer's disease. Lancet Neurol. 2015;14(4):388-405. doi: 10.1016/S14744422(15)70016-5.

15. Chin-Chan M, Navarro-Yepes J, Quintanilla-Vega B. Environmental pollutants as risk factors for neurodegenerative disorders: Alzheimer and Parkinson diseases. Front Cell Neurosci. 2015;9:124. doi: 10.3389/fncel.2015.00124.

16. Arnold SE, Arvanitakis Z, Macauley-Rambach SL, Koenig AM, Wang HY, Ahima RS, et al. Brain insulin resistance in type 2 diabetes and Alzheimer disease: concepts and conundrums. Nat Rev Neurol. 2018;14(3):168-181. doi: 10.1038/ nrneurol.2017.185

17. Qiu C, Fratiglioni L. Aging without dementia is achievable: current evidence from epidemiological research. J Alzheimers Dis. 2018;62(3):933-942. doi: 10.3233/JAD-171037.

18. Ernst E. Herbal medicines-they are popular, but are they also safe? Eur J Clin Pharmacol. 2006;62(1):1-2. doi: 10.1007/ s00228-005-0070-2.

19. José Bagur M, Alonso Salinas GL, Jiménez-Monreal AM, Chaouqi S, Llorens S, Martínez-Tomé M, et al. Saffron: An old medicinal plant and a potential novel functional food. Molecules. 2017;23(1):30. doi: 10.3390/molecules23010030.

20. Akhondzadeh S, Abbasi SH. Herbal medicine in the treatment of Alzheimer's disease. Am J Alzheimers Dis Other Demen. 2006;21(2):113-8. doi: 10.1177/153331750602100211.

21. Schmidt M, Betti G, Hensel A. Saffron in phytotherapy: pharmacology and clinical uses. Wien Med Wochenschr. 2007;157(13-14):315-9. doi: 10.1007/s10354-007-0428-4.

22. Fatehi M, Rashidabady T, Fatehi-Hassanabad Z. Effects of Crocus sativus petals' extract on rat blood pressure and on responses induced by electrical field stimulation in the rat isolated vas deferens and guinea-pig ileum. J Ethnopharmacol. 2003;84(2-3):199-203. doi: 10.1016/s0378-8741(02)002994.

23. Sachdeva J, Tanwar V, Golechha M, Siddiqui KM, Nag TC, Ray $\mathrm{R}$, et al. Crocus sativus L.(saffron) attenuates isoproterenolinduced myocardial injury via preserving cardiac functions and strengthening antioxidant defense system. Exp Toxicol Pathol. 2012;64(6):557-64. doi: 10.1016/j.etp.2010.11.013.

24. Khorasanchi Z, Shafiee M, Kermanshahi F, Khazaei M, Ryzhikov M, Parizadeh MR, et al. Crocus sativus a natural food coloring and flavoring has potent anti-tumor properties. Phytomedicine. 2018;43:21-27. doi: 10.1016/j. phymed.2018.03.041

25. Yaribeygi $H$, Zare $V$, Butler AE, Barreto GE, Sahebkar A. Antidiabetic potential of saffron and its active constituents. J Cell Physiol. 2019;234(6):8610-8617. doi: 10.1002/jcp.27843

26. Wali AF, Alchamat HAA, Hariri HK, Hariri BK, Menzes GA, Zehra $U$, et al. Antioxidant, Antimicrobial, Antidiabetic and Cytotoxic Activity of Crocus sativus L. Petals. Applied Sciences. 2020;10(4):1519. doi: 10.3390/app10041519

27. Moallem SA, Hariri AT, Mahmoudi M, Hosseinzadeh $H$. Effect of aqueous extract of Crocus sativus L.(saffron) stigma against subacute effect of diazinon on specific biomarkers in rats. Toxicol Ind Health. 2014;30(2):141-146. doi: 10.1177/0748233712452609

28. Bani S, Pandey A, Agnihotri VK, Pathania V, Singh B. Selective Th2 upregulation by Crocus sativus: a neutraceutical spice. Evid Based Complement Alternat Med. 2011;2011. doi: $10.1155 / 2011 / 639862$

29. Bayrami G, Boskabady M. The potential effect of the extract of Crocus sativus and safranal on the total and differential white blood cells of ovalbumin-sensitized guinea pigs. Res Pharm Sci. $2012 ; 7(4): 249$.

30. Halataei BaS, Khosravi M, Arbabian S, Sahraei H, Golmanesh L, Zardooz H, et al. Saffron (Crocus sativus) aqueous extract and its constituent crocin reduces stress-induced anorexia in mice. Phytother Res. 2011;25(12):1833-8. doi: 10.1002/ ptr.3495

31. Byrami G, Boskabady MH, Jalali S, Farkhondeh T. The effect of the extract of Crocus sativus on tracheal responsiveness and plasma levels of IL-4, IFN- $\boldsymbol{\gamma}$, total NO and nitrite in ovalbumin sensitized Guinea-pigs. J Ethnopharmacol. 2013;147(2):5305. doi: 10.1016/j.jep.2013.03.014

32. Mohammadzadeh-Moghadam H, Nazari SM, Shamsa A, Kamalinejad M, Esmaeeli H, Asadpour AA, et al. Effects of a topical saffron (Crocus sativus $\mathrm{L}$ ) gel on erectile dysfunction in diabetics: A randomized, parallel-group, double-blind, placebo-controlled trial. J Evid Based Complementary Altern Med. 2015;20(4):283-286. doi: 10.1177/2156587215583756

33. Lopresti AL, Smith SJ, Hood SD, Drummond PD. Efficacy

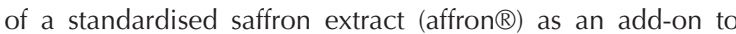
antidepressant medication for the treatment of persistent depressive symptoms in adults: A randomised, doubleblind, placebo-controlled study. J Psychopharmacol. 2019;33(11):1415-27. doi: 10.1177/0269881119867703

34. Hosseinzadeh H, Talebzadeh F. Anticonvulsant evaluation of safranal and crocin from Crocus sativus in mice. Fitoterapia. 2005;76(7-8):722-4. doi: 10.1016/j.fitote.2005.07.008

35. Amin B, Malekzadeh M, Heidari MR, Hosseinzadeh H. Effect of Crocus sativus extracts and its active constituent safranal on the harmaline-induced tremor in mice. Iran J Basic Med Sci. 2015;18(5):449

36. Hosseinzadeh H, Jahanian Z. Effect of Crocus sativus L.(saffron) stigma and its constituents, crocin and safranal, on morphine withdrawal syndrome in mice. Phytother Res. 2010;24(5):72630. doi: 10.1002/ptr.3011

37. Hosseinzadeh $\mathrm{H}$, Khosravan V. Anticonvulsant effect of aqueous and ethanolic extracts of Crocus sativus I stigmas in mice. BMC Pharmacol. 2002. doi: 10.1186/1471-2210-2-7

38. Sadeghnia HR, Kamkar M, Assadpour E, Boroushaki MT, Ghorbani A. Protective effect of safranal, a constituent of Crocus sativus, on quinolinic acid-induced oxidative damage in rat hippocampus. Iran J Basic Med Sci. 2013;16(1):73.

39. Ahmad AS, Ansari MA, Ahmad M, Saleem S, Yousuf S, Hoda 
MN, et al. Neuroprotection by crocetin in a hemi-parkinsonian rat model. Pharmacol Biochem Behav. 2005;81(4):805-13. doi: 10.1016/j.pbb.2005.06.007

40. Saleem S, Ahmad M, Ahmad AS, Yousuf S, Ansari MA, Khan $M B$, et al. Effect of Saffron (Crocus sativus) on neurobehavioral and neurochemical changes in cerebral ischemia in rats. J Med Food. 2006;9(2):246-53. doi: 10.1089/jmf.2006.9.246

41. Linardaki ZI, Orkoula MG, Kokkosis AG, Lamari FN, Margarity M. Investigation of the neuroprotective action of saffron (Crocus sativus L.) in aluminum-exposed adult mice through behavioral and neurobiochemical assessment. Food Chem Toxicol. 2013;52:163-70. doi: 10.1016/j.fct.2012.11.016

42. Fernández-Albarral JA, Ramírez Al, de Hoz R, López-Villarín N, Salobrar-García E, López-Cuenca I, et al. Neuroprotective and Anti-Inflammatory Effects of a Hydrophilic Saffron Extract in a Model of Glaucoma. Int J Mol Sci. 2019;20(17):4110. doi: 10.3390/ijms20174110

43. Fernández-Albarral JA, de Hoz R, Ramírez Al, López-Villarín N, Salobrar-García E, López-Cuenca I, et al. Beneficial effects of saffron (Crocus sativus L.) in ocular pathologies, particularly neurodegenerative retinal diseases. Neural Regen Res. 2020;15(8):1408-16. doi: 10.4103/1673-5374.274325

44. Broadhead GK, Grigg JR, McCluskey P, Hong T, Schlub TE, Chang AA. Saffron therapy for the treatment of mild/moderate age-related macular degeneration: a randomised clinical trial. Graefes Arch Clin Exp Ophthalmol. 2019;257(1):31-40. doi: 10.1007/s00417-018-4163-x

45. Abe K, Sugiura M, Shoyama Y, Saito H. Crocin antagonizes ethanol inhibition of NMDA receptor-mediated responses in rat hippocampal neurons. Brain Res. 1998;787(1):132-8. doi: 10.1016/s0006-8993(97)01505-9

46. Sreenu G, Banala RR, Reddy KP. Saffron extract's protective effects against arsenic induced excitotoxicity and learning disabilities in male Wistar rats. Int J Bioassay. 2015;4:4223-9. doi:10.21746/IJBIO.2015.08.0012

47. Naghibi SM, Hosseini M, Khani F, Rahimi M, Vafaee F, Rakhshandeh $\mathrm{H}$, et al. Effect of aqueous extract of Crocus sativus L. on morphine-induced memory impairment. Adv Pharmacol Sci. 2012;2012. doi: 10.1155/2012/494367

48. Georgiadou G, Grivas V, Tarantilis PA, Pitsikas N. Crocins, the active constituents of Crocus sativus L., counteracted ketamineinduced behavioural deficits in rats. Psychopharmacology (Berl). 2014;231(4):717-26. doi: 10.1007/s00213-013-3293-4

49. Papandreou MA, Kanakis CD, Polissiou MG, Efthimiopoulos S, Cordopatis P, Margarity $\mathrm{M}$, et al. Inhibitory activity on amyloid- $\boldsymbol{\beta}$ aggregation and antioxidant properties of Crocus sativus stigmas extract and its crocin constituents. J Agric Food Chem. 2006;54(23):8762-8. doi: 10.1021/jf061932a

50. Al-Snafi AE. The pharmacology of Crocus sativus-A review. IOSR Journal of Pharmacy. 2016;6(6):8-38.

51. Bukhari SI, Manzoor M, Dhar M. A comprehensive review of the pharmacological potential of Crocus sativus and its bioactive apocarotenoids. Biomed Pharmacother. 2018;98:733-45. doi: 10.1016/j.biopha.2017.12.090

52. Mykhailenko O, Kovalyov V, Goryacha O, Ivanauskas L, Georgiyants V. Biologically active compounds and pharmacological activities of species of the genus Crocus: A review. Phytochemistry. 2019;162:56-89. doi: 10.1016/j. phytochem.2019.02.004

53. Heitmar R, Brown J, Kyrou I. Saffron (Crocus sativus L.) in ocular diseases: A narrative review of the existing evidence from clinical studies. Nutrients. 2019;11(3):649. doi: 10.3390/ nu11030649

54. Lautenschläger $M$, Sendker J, Hüwel S, Galla HJ, Brandt $S$, Düfer $M$, et al. Intestinal formation of trans-crocetin from saffron extract (Crocus sativus L.) and in vitro permeation through intestinal and blood brain barrier. Phytomedicine. 2015;22(1):36-44. doi: 10.1016/j.phymed.2014.10.009
55. Xi L, Qian Z, Du P, Fu J. Pharmacokinetic properties of crocin (crocetin digentiobiose ester) following oral administration in rats. Phytomedicine. 2007;14(9):633-636. doi: 10.1016/j. phymed.2006.11.028

56. Yang N, Sun RB, Chen XL, Zhen L, Ge C, Zhao YQ, et al. In vitro assessment of the glucose-lowering effects of berberrubine-9-O- $\beta$-D-glucuronide, an active metabolite of berberrubine. Acta Pharmacol Sin. 2017;38(3):351-61. doi: 10.1038/aps.2016.120

57. Asai A, Nakano T, Takahashi M, Nagao A. Orally administered crocetin and crocins are absorbed into blood plasma as crocetin and its glucuronide conjugates in mice. J Agric Food Chem. 2005;53(18):7302-6. doi: 10.1021/jf0509355

58. Hosseini A, Razavi BM, Hosseinzadeh H. Pharmacokinetic properties of saffron and its active components. Eur J Drug Metab Pharmacokinet. 2018;43(4):383-90. doi: 10.1007/ s13318-017-0449-3

59. Christodoulou E, Grafakou ME, Skaltsa E, Kadoglou N, Kostomitsopoulos N, Valsami G. Preparation, chemical characterization and determination of crocetin's pharmacokinetics after oral and intravenous administration of saffron (Crocus sativus L.) aqueous extract to C57/BL 6] mice. J Pharm Pharmacol. 2019;71(5):753-64. doi: 10.1111/ jphp. 13055

60. O'Brien RJ, Wong PC. Amyloid precursor protein processing and Alzheimer's disease. Annu Rev Neurosci. 2011;34:185204. doi: 10.1146/annurev-neuro-061010-113613

61. Harkany T, Abraham I, Timmerman W, Laskay G, Tóth B, Sasvári $M$, et al. $\beta$-Amyloid neurotoxicity is mediated by a glutamate-triggered excitotoxic cascade in rat nucleus basalis. Eur J Neurosci. 2000;12(8):2735-45. doi: 10.1046/j.14609568.2000.00164.x

62. Qiu C, Kivipelto M, von Strauss E. Epidemiology of Alzheimer's disease: occurrence, determinants, and strategies toward intervention. Dialogues Clin Neurosci. 2009;11(2):111. doi: 10.31887/DCNS.2009.11.2/cqiu

63. Kirkitadze MD, Kowalska A. Molecular mechanisms initiating amyloid beta-fibril formation in Alzheimer's disease. Acta Biochim Pol. 2005;52(2):417-423.

64. Shankar GM, Walsh DM. Alzheimer's disease: synaptic dysfunction and A $\beta$. Mol Neurodegener. 2009;4(1):48. doi: 10.1186/1750-1326-4-48

65. Sadigh-Eteghad S, Talebi M, Farhoudi M, Golzari SE, Sabermarouf B, Mahmoudi J. Beta-amyloid exhibits antagonistic effects on alpha 7 nicotinic acetylcholine receptors in orchestrated manner. Journal of Medical Hypotheses and Ideas. 2014;8(2):49-52. doi: 10.1016/j.jmhi.2014.01.001

66. Kontush A, Berndt C, Weber W, Akopyan V, Arlt S, Schippling $S$, et al. Amyloid- $\beta$ is an antioxidant for lipoproteins in cerebrospinal fluid and plasma. Free Radic Biol Med.. 2001;30(1):119-28. doi: 10.1016/s0891-5849(00)00458-5

67. Nunomura A, Castellani RJ, Lee H-g, Moreira PI, Zhu X, Perry $G$ et al. Neuropathology in Alzheimer's disease: awaking from a hundred-year-old dream. Sci Aging Knowledge Environ. 2006;8:e10. doi: 10.1126/sageke.2006.8.pe10

68. Vinters HV. Cerebral amyloid angiopathy. A critical review. Stroke. 1987;18(2):311-24. doi: 10.1161/01.str.18.2.311

69. Ellis R, Olichney JM, Thal L, Mirra SS, Morris JC, Beekly D et al. Cerebral amyloid angiopathy in the brains of patients with Alzheimer's disease: the CERAD experience, Part XV. Neurology. 1996;46(6):1592-6. doi: 10.1212/wnl.46.6.1592

70. Attems J, Yamaguchi H, Saido TC, Thal DR. Capillary CAA and perivascular A $\beta$-deposition: two distinct features of Alzheimer's disease pathology. J Neurol Sci. 2010;299(1-2):155-62. doi: 10.1016/j.jns.2010.08.030

71. Kihara T, Shimohama S. Alzheimer's disease and acetylcholine receptors. Acta Neurobiol Exp (Wars). 2004;64(1):99-106.

72. Sadigh-Eteghad S, Sabermarouf B, Majdi A, Talebi M, 
Farhoudi M, Mahmoudi J. Amyloid-beta: a crucial factor in Alzheimer's disease. Med Princ Pract. 2015;24(1):1-10. doi: 10.1159/000369101

73. Ridolfi E, Barone C, Scarpini E, Galimberti D. The role of the innate immune system in Alzheimer's disease and frontotemporal lobar degeneration: an eye on microglia. Clin Dev Immunol. 2013;2013. doi: 10.1155/2013/939786

74. Balducci C, Beeg M, Stravalaci M, Bastone A, Sclip A, Biasini E, et al. Synthetic amyloid- $\beta$ oligomers impair long-term memory independently of cellular prion protein Proc Natl Acad Sci U S A. 2010;107(5):2295-2300. doi: 10.1073/pnas.0911829107

75. Barry AE, Klyubin I, Mc Donald JM, Mably AJ, Farrell MA, Scott $M$, et al. Alzheimer's disease brain-derived amyloid- $\beta$-mediated inhibition of LTP in vivo is prevented by immunotargeting cellular prion protein. J Neurosci. 2011;31(20):7259-63. doi: 10.1523/JNEUROSCI.6500-10.2011

76. Shen CL, Fitzgerald MC, Murphy RM. Effect of acid predissolution on fibril size and fibril flexibility of synthetic beta-amyloid peptide. Biophys J. 1994;67(3):1238-46. doi:10.1016/S0006-3495(94)80593-4

77. Hardy J, Selkoe DJ. The amyloid hypothesis of Alzheimer's disease: progress and problems on the road to therapeutics. Science. 2002;297(5580):353-6. doi: 10.1126/ science. 1072994.

78. Kittelberger KA, Piazza F, Tesco G, Reijmers LG. Natural amyloid-beta oligomers acutely impair the formation of a contextual fear memory in mice. PLoS One. 2012;7(1):e29940. doi: 10.1371/journal.pone.0029940.

79. Davidowitz EJ, Chatterjee I, Moe JG. Targeting tau oligomers for therapeutic development for Alzheimer's disease and tauopathies. Biotechnology. 2008;4:47-64.

80. Götz J, Probst A, Spillantini MG, Schäfer T, Jakes R, Bürki K, et al. Somatodendritic localization and hyperphosphorylation of tau protein in transgenic mice expressing the longest human brain tau isoform. EMBO J. 1995;14(7):1304-1313.

81. Buée L, Bussière $T$, Buée-Scherrer $V$, Delacourte $A$, Hof PR. Tau protein isoforms, phosphorylation and role in neurodegenerative disorders. Brain Res Brain Res Rev. 2000;33(1):95-130. doi: 10.1016/s0165-0173(00)00019-9

82. Brion J-P. Neurofibrillary tangles and Alzheimer's disease. Eur Neurol. 1998;40(3):130-40. doi: 10.1159/000007969

83. Kimura T, Yamashita S, Fukuda T, Park JM, Murayama M, Mizoroki T et al. Hyperphosphorylated tau in parahippocampal cortex impairs place learning in aged mice expressing wildtype human tau. EMBO J. 2007;26(24):5143-52. doi: 10.1038/ sj.emboj.7601917

84. Kimura T, Whitcomb DJ, Jo J, Regan P, Piers T, Heo S, et al. Microtubule-associated protein tau is essential for long-term depression in the hippocampus. Philos Trans R Soc Lond B Biol Sci. 2014;369(1633):20130144. doi: 10.1098/rstb.2013.0144

85. Mohorko N, Bresjanac M. Tau protein and human tauopathies: an overwiev. Slovenian Medical Journal. 2008;77.

86. Goedert M, Spillantini MG. A century of Alzheimer's disease. Science. 2006;314(5800):777-81. doi: 10.1126/ science.1132814.

87. Braak H, Del Tredici K. Where, when, and in what form does sporadic Alzheimer's disease begin? Curr Opin Neurol. 2012;25(6):708-14. doi: 10.1097/WCO.0b013e32835a3432

88. Santa-Maria I, Haggiagi A, Liu X, Wasserscheid J, Nelson PT, Dewar K, et al. The MAPT H1 haplotype is associated with tangle-predominant dementia. Acta neuropathol. 2012;124(5):693-704. doi: 10.1007/s00401-012-1017-1

89. Haan MN, Shemanski L, Jagust WJ, Manolio TA, Kuller L. The role of apoe epsilon4 in modulating effects of other risk factors for cognitive decline in elderly persons. Neuroimage. 2018;172:118-29. doi: 10.1016/j.neuroimage.2017.12.027.

90. Lahoz C, Schaefer EJ, Cupples LA, Wilson PW, Levy D, Osgood $\mathrm{D}$, et al. Apolipoprotein $\mathrm{E}$ genotype and cardiovascular disease in the Framingham Heart Study. Atherosclerosis. 2001;154(3):529-37. doi: 10.1016/s0021-9150(00)00570-0

91. Mahley RW, Rall SC Jr. Apolipoprotein E: far more than a lipid transport protein. Annu Rev Genomics Hum Genet. 2000;1(1):507-37. doi: 10.1146/annurev.genom.1.1.507

92. Peila R, Rodriguez BL, Launer LJ. Type 2 diabetes, APOE gene, and the risk for dementia and related pathologies: The Honolulu-Asia Aging Study. Diabetes. 2002;51(4):1256-62. doi: $10.2337 /$ diabetes.51.4.1256

93. Corder EH, Saunders AM, Strittmatter WJ, Schmechel DE, Gaskell PC, Small GW, et al. Gene dose of apolipoprotein E type 4 allele and the risk of Alzheimer's disease in late onset families. Science. 1993;261(5123):921-3. doi: 10.1126/ science.8346443.

94. Farrer LA, Cupples LA, Haines JL, Hyman B, Kukull WA, Mayeux R, et al. Effects of age, sex, and ethnicity on the association between apolipoprotein E genotype and Alzheimer disease: a meta-analysis. JAMA. 1997;278(16):1349-56.

95. Talbot C, Lendon C, Craddock N, Shears S, Morris JC, Goate A. Protection against Alzheimer's disease with apoE epsilon2. Lancet. 1994:1432-2. doi: 10.1016/s0140-6736(94)92557-7

96. Harold D, Abraham R, Hollingworth P, Sims R, Gerrish A, Hamshere ML, et al. Erratum: Genome-wide association study identifies variants at CLU and PICALM associated with Alzheimer's disease (Nature Genetics)(2009) 41 (1088-1093). Nat Genet. 2009;41(10). doi: 10.1038/ng.440

97. Lambert JC, Heath S, Even G, Campion D, Sleegers K, Hiltunen $M$, et al. Genome-wide association study identifies variants at CLU and CR1 associated with Alzheimer's disease. Nat Genet. 2009;41(10):1094. doi: 10.1038/ng.440

98. Hauser PS, Ryan RO. Impact of apolipoprotein E on Alzheimer's disease. Curr Alzheimer Res. 2013;10(8):809-17. doi: $\quad 10.2174 / 15672050113109990156$

99. Glorioso CA, Pfenning AR, Lee SS, Bennett DA, Sibille EL, Kellis $M$, et al. Rate of brain aging and APOE $\varepsilon 4$ are synergistic risk factors for Alzheimer's disease. Life Sci Alliance. 2019;2(3):e201900303. doi: 10.26508/lsa.201900303.

100. Bales KR, Liu F, Wu S, Lin S, Koger D, DeLong C, et al. Human APOE isoform-dependent effects on brain $\beta$-amyloid levels in PDAPP transgenic mice. J Neurosci. 2009;29(21):6771-9. doi: 10.1523/JNEUROSCI.0887-09.2009

101. Castellano JM, Kim J, Stewart FR, Jiang H, DeMattos RB, Patterson BW, et al. Human apoE isoforms differentially regulate brain amyloid- $\beta$ peptide clearance. Sci Transl Med. 2011;3(89):89ra57. doi: 10.1126/scitranslmed.3002156

102. Huang Y-WA, Zhou B, Wernig M, Südhof TC. ApoE2, ApoE3, and ApoE4 differentially stimulate APP transcription and A $\beta$ secretion. Cell. 2017;168(3):427-441.e421. doi: 10.1016/j. cell.2016.12.044

103. Bales KR, Verina T, Dodel RC, Du Y, Altstiel L, Bender M et al. Lack of apolipoprotein $\mathrm{E}$ dramatically reduces amyloid $\beta$-peptide deposition. Nat Genet. 1997;17(3):263-4. doi: 10.1038/ng1197-263

104. Kok E, Haikonen S, Luoto T, Huhtala H, Goebeler S, Haapasalo $\mathrm{H}$, et al. Apolipoprotein E-dependent accumulation of Alzheimer disease-related lesions begins in middle age. Ann Neurol. 2009;65(6):650-7. doi: 10.1002/ana.21696

105. Polvikoski T, Sulkava R, Haltia M, Kainulainen K, Vuorio A, Verkkoniemi A et al. Apolipoprotein E, dementia, and cortical deposition of $\beta$-amyloid protein. $N$ Engl J Med. 1995;333(19):1242-8. doi: 10.1073/pnas.90.20.9649

106. Schmechel D, Saunders A, Strittmatter W, Crain BJ, Hulette $\mathrm{CM}$, Joo $\mathrm{SH}$, et al. Increased amyloid beta-peptide deposition in cerebral cortex as a consequence of apolipoprotein $E$ genotype in late-onset Alzheimer disease. Proc Natl Acad Sci U S A. 1993;90(20):9649-53. doi: 10.1073/pnas.90.20.9649

107. Berlau DJ, Corrada MM, Head E, Kawas CH. APOE $\varepsilon 2$ is associated with intact cognition but increased Alzheimer 
pathology in the oldest old. Neurology. 2009;72(9):829-34. doi: 10.1212/01.wnl.0000343853.00346.a4

108. Etnier JL, Caselli RJ, Reiman EM, Alexander GE, Sibley BA, Tessier D, et al. Cognitive performance in older women relative to ApoE- $\varepsilon 4$ genotype and aerobic fitness. Med Sci Sports Exerc. 2007;39(1):199-207. doi: 10.1249/01. mss.0000239399.85955.5e

109. Brown BM, Peiffer J, Taddei K, Lui JK, Laws SM, Gupta VB, et al. Physical activity and amyloid- $\beta$ plasma and brain levels: results from the Australian Imaging, Biomarkers and Lifestyle Study of Ageing. Mol Psychiatry. 2013;18(8):875-881. doi: 10.1038/mp.2012.107

110. Head D, Bugg JM, Goate AM, Fagan AM, Mintun MA, Benzinger , $T$ et al. Exercise engagement as a moderator of the effects of APOE genotype on amyloid deposition. Arch Neurol. 2012;69(5):636-43. doi: 10.1001/archneurol.2011.845

111. Berkowitz C, Mosconi L, Rahman A, Scheyer O, Hristov H, Isaacson RS. Clinical application of APOE in Alzheimer's prevention: a precision medicine approach. J Prev Alzheimers Dis. 2018;5(4):245-52. doi: 10.14283/jpad.2018.35

112. Durazzo TC, Mattsson N, Weiner MW, Initiative AsDN. Interaction of cigarette smoking history with apoe genotype and age on amyloid level, glucose metabolism, and neurocognition in cognitively normal elders. Nicotine Tob Res. 2015;18(2):204-11. doi: 10.1093/ntr/ntv075

113. Kivipelto $M$, Rovio $S$, Ngandu $T$, Kåreholt I, Eskelinen $M$, Winblad B, et al. Apolipoprotein E $\varepsilon 4$ magnifies lifestyle risks for dementia: a population-based study. J Cell Mol Med. 2008;12(6b):2762-71. doi: 10.1111/j.15824934.2008.00296.x

114. Downer B, Zanjani F, Fardo DW. The relationship between midlife and late life alcohol consumption, APOE e4 and the decline in learning and memory among older adults. Alcohol Alcohol. 2014;49(1):17-22. doi: 10.1093/alcalc/agt144

115. Premkumar K, Abraham SK, Santhiya S, Ramesh A. Protective effects of saffron (Crocus sativus Linn.) on genotoxinsinduced oxidative stress in Swiss albino mice. Phytother Res. 2003;17(6):614-17. doi: 10.1002/ptr.1209

116. Soeda S, Aritake K, Urade Y, Sato H, Shoyama Y. Neuroprotective activities of saffron and crocin. The Benefits of Natural Products for Neurodegenerative Diseases: Springer; 2016:275-92. doi:10.1007/978-3-319-28383-8_14

117. Batish D, Singh H, Setia N, Kaur S, Kohli R. 2-Benzoxazolinone (BOA) induced oxidative stress, lipid peroxidation and changes in some antioxidant enzyme activities in mung bean (Phaseolus aureus). Plant Physiol Biochem. 2006;44(1112):819-27. doi: 10.1016/j.plaphy.2006.10.014

118. Bodnoff SR, Humphreys AG, Lehman JC, Diamond DM, Rose GM, Meaney MJ. Enduring effects of chronic corticosterone treatment on spatial learning, synaptic plasticity, and hippocampal neuropathology in young and mid-aged rats. J Neurosci. 1995;15(1):61-9. doi: 10.1523/ JNEUROSCI.15-01-00061.1995

119. Zafir A, Banu N. Modulation of in vivo oxidative status by exogenous corticosterone and restraint stress in rats. Stress. 2009;12(2):167-177. doi: 10.1080/10253890802234168

120. Galea L, McEwen B, Tanapat P, Deak T, Spencer R, Dhabhar F. Sex differences in dendritic atrophy of CA3 pyramidal neurons in response to chronic restraint stress. Neuroscience. 1997;81(3):689-97. doi: 10.1016/s0306-4522(97)00233-9

121. Magariños AMa, Orchinik M, McEwen BS. Morphological changes in the hippocampal CA3 region induced by noninvasive glucocorticoid administration: a paradox. Brain Res. 1998;809(2):314-8. doi: 10.1016/s0006-8993(98)00882-8

122. Asdaq SMB, Inamdar MN. Potential of Crocus sativus (saffron) and its constituent, crocin, as hypolipidemic and antioxidant in rats. Appl Biochem Biotechnol. 2010;162(2):358-72. doi: 10.1007/s12010-009-8740-7
123. Kanakis C, Tarantilis P, Pappas C, Bariyanga J, Tajmir-Riahi $\mathrm{H}$, Polissiou M. An overview of structural features of DNA and RNA complexes with saffron compounds: Models and antioxidant activity. J Photochem Photobiol B. 2009;95(3):20412. doi: 10.1016/j.jphotobiol.2009.03.006

124. Das SK, Prusty A, Samantaray D, Hasan M, Jena S, Patra $\mathrm{JK}$, et al. Effect of Xylocarpus granatum Bark Extract on Amelioration of Hyperglycaemia and Oxidative Stress Associated Complications in STZ-Induced Diabetic Mice. Evid Based Complement Alternat Med. 2019;2019:8493190. doi: 10.1155/2019/8493190.

125. Aydin Dilsiz S, Bacanli M, Anlar H, Çal T, Arı N, Ündeğer Bucurgat Ü, et al. Preventive role of Pycnogenol (R) against the hyperglycemia-induced oxidative stress and DNA damage in diabetic rats. Food Chem Toxicol. 2019 Feb;124:54-63. doi: 10.1016/j.fct.2018.11.038.

126. Del-Angel D, Martínez N, Cruz M, Urrutia E, Riverón-Negrete L, Abdullaev F. Saffron extract ameliorates oxidative damage and mitochondrial dysfunction in the rat brain. Paper presented at: II International Symposium on Saffron Biology and Technology 7392006. doi: 10.17660/ActaHortic.2007.739.47

127. Sh A, El-Azime A, NH S, N A E. Efficacy of aqueous extract of saffron (Crocus sativus L.) in modulating radiation-induced brain and eye retina damage in rats. The Egyptian Journal of Hospital Medicine. 2014;54(1):101-8. doi: 10.12816/0002436

128. Finley JW, Gao S. A perspective on Crocus sativus L. (Saffron) constituent crocin: a potent water-soluble antioxidant and potential therapy for Alzheimer's disease. J Agric Food Chem. 2017;65(5):1005-20. doi: 10.1021/acs.jafc.6b04398

129. Chen L, Qi Y, Yang X. Neuroprotective effects of crocin against oxidative stress induced by ischemia/reperfusion injury in rat retina. Ophthalmic Res. 2015;54(3):157-68. doi: 10.1159/000439026

130. Rahiman N, Akaberi M, Sahebkar A, Emami SA, TayaraniNajaran Z. Protective effects of saffron and its active components against oxidative stress and apoptosis in endothelial cells. Microvasc Res. 2018;118:82-9. doi: 10.1016/j.mvr.2018.03.003

131. Ibach B, Haen E. Acetylcholinesterase inhibition in Alzheimer's Disease. Curr Pharm Des. 2004;10(3):231-51. doi: $\quad 10.2174 / 1381612043386509$

132. Mega MS. The cholinergic deficit in Alzheimer's disease: impact on cognition, behaviour and function. Int J Neuropsychopharmacol. 2000;3(Supplement_2):S3-S12. doi: 10.1017/S1461145700001942

133. Birks JS. Cholinesterase inhibitors for Alzheimer's disease. Cochrane Database Syst Rev. 2006;(1):CD005593. doi: 10.1002/14651858.CD005593.

134. Howland RH. Drug therapies for cognitive impairment and dementia. J Psychosoc Nurs Ment Health Serv. Journal of psychosocial nursing and mental health services. 2010;48(4):11-4. doi: 10.3928/02793695-20100311-01

135. Ademosun AO, Oboh G. Inhibition of acetylcholinesterase activity and $\mathrm{Fe} 2+-$-induced lipid peroxidation in rat brain in vitro by some citrus fruit juices. J Med Food. 2012;15(5):42834. doi: 10.1089/jmf.2011.0226

136. Papandreou MA, Tsachaki M, Efthimiopoulos S, Cordopatis $P$, Lamari FN, Margarity M. Memory enhancing effects of saffron in aged mice are correlated with antioxidant protection. Behav Brain Res. 2011;219(2):197-204. doi: 10.1016/j. bbr.2011.01.007

137. Rafieipour F, Hadipour E, Emami SA, Asili J, Tayarani-Najaran Z. Safranal protects against beta-amyloid peptide-induced cell toxicity in PC12 cells via MAPK and $\mathrm{PI} 3 \mathrm{~K}$ pathways. Metab Brain Dis. 2019;34(1):165-72. doi: 10.1016/j. pbb.2015.10.011

138. Rashedinia M, Lari P, Abnous K, Hosseinzadeh H. Protective effect of crocin on acrolein-induced tau phosphorylation in 
the rat brain. Acta Neurobiol Exp (Wars). 2015;75(2):208-19.

139. Kirouac L, Rajic AJ, Cribbs DH, Padmanabhan J. Activation of Ras-ERK signaling and GSK-3 by amyloid precursor protein and amyloid beta facilitates neurodegeneration in Alzheimer's disease. eNeuro. 2017 Mar 27;4(2):ENEURO.0149-16.2017. doi: 10.1523/ENEURO.0149-16.2017.

140. Ghahghaei A, Bathaie SZ, Bahraminejad E. Mechanisms of the effects of crocin on aggregation and deposition of A $\beta 1-40$ fibrils in Alzheimer's disease. Int J Pept Res The. 2012;18(4):347-51. doi: 10.1007/s10989-012-9308-x

141. Ghahghaei A, Bathaie SZ, Kheirkhah H, Bahraminejad E. The protective effect of crocin on the amyloid fibril formation of Aß42 peptide in vitro. Cell Mol Biol Lett. 2013;18(3):328-39. doi: 10.2478/s11658-013-0092-1

142. Morelli S, Salerno S, Piscioneri A, Tasselli F, Drioli E, De Bartolo L. Neuronal membrane bioreactor as a tool for testing crocin neuroprotective effect in Alzheimer's disease. Chem Eng J. 2016;305:69-78. doi:10.1016/j.cej.2016.01.035

143. Asadi F, Jamshidi AH, Khodagholi F, Yans A, Azimi L, Faizi $M$, et al. Reversal effects of crocin on amyloid $\beta$-induced memory deficit: modification of autophagy or apoptosis markers. Pharmacol Biochem Behav. 2015;139(Pt A):47-58. doi: $\quad$ 10.1016/j.pbb.2015.10.011.

144. Soeda S, Ochiai T, Paopong L, Tanaka H, Shoyama Y, Shimeno $H$. Crocin suppresses tumor necrosis factor- $\alpha$-induced cell death of neuronally differentiated PC-12 cells. Life Sci. 2001;69(24):2887-98. doi: 10.1016/s0024-3205(01)01357-1

145. Baluchnejadmojarad T, Mohamadi-Zarch S-M, Roghani M. Safranal, an active ingredient of saffron, attenuates cognitive deficits in amyloid $\beta$-induced rat model of Alzheimer's disease: underlying mechanisms. Metab Brain Dis. 2019;34(6):174759. doi: 10.1007/s11011-019-00481-6

146. Holsinger RD, McLean CA, Beyreuther K, Masters CL, Evin G. Increased expression of the amyloid precursor $\beta$-secretase in Alzheimer's disease. Ann Neurol. 2002;51(6):783-6. doi: 10.1002/ana.10208

147. Kayed R, Lasagna-Reeves CA. Molecular mechanisms of amyloid oligomers toxicity. J Alzheimers Dis. 2013;33(s1):S67-S78. doi: 10.3233/JAD-2012-129001

148. Batarseh YS, Bharate SS, Kumar V, Kumar A, Vishwakarma RA, Bharate SB, et al. Crocus sativus extract tightens the bloodbrain barrier, reduces amyloid $\beta$ load and related toxicity in 5XFAD mice. ACS Chem Neurosci. 2017;8(8):1756-66. doi: 10.1021/acschemneuro.7b00101

149. Karakani AM, Riazi G, Mahmood Ghaffari S, Ahmadian S, Mokhtari F, Jalili Firuzi M, et al. Inhibitory effect of corcin on aggregation of $1 \mathrm{~N} / 4 \mathrm{R}$ human tau protein in vitro. Iran J Basic Med Sci. 2015;18(5):485-92.

150. Mohammadzadeh L, Abnous K, Razavi BM, Hosseinzadeh H. Crocin-protected malathion-induced spatial memory deficits by inhibiting TAU protein hyperphosphorylation and antiapoptotic effects. Nutr Neurosci. 2020;23(3):221-236. doi: $\quad 10.1080 / 1028415 X .2018 .1492772$

151. Chawla A, Boisvert WA, Lee $C H$, Laffitte BA, Barak $Y$, Joseph $\mathrm{SB}$, et al. A PPAR $\gamma$-LXR-ABCA1 pathway in macrophages is involved in cholesterol efflux and atherogenesis. Mol Cell. 2001;7(1):161-71. doi: 10.1016/s1097-2765(01)00164-2

152. Qosa H, Abuasal BS, Romero IA, Weksler B, Couraud PO, Keller JN, et al. Differences in amyloid- $\beta$ clearance across mouse and human blood-brain barrier models: kinetic analysis and mechanistic modeling. Neuropharmacology. 2014;79:668-78. doi: 10.1016/j.neuropharm.2014.01.023

153. Wahrle SE, Jiang $H$, Parsadanian $M$, Han X, Fryer JD, Kowalewski T, et al. ABCA1 is required for normal central nervous system ApoE levels and for lipidation of astrocytesecreted apoE. J Biol Chem. 2004;279(39):40987-93. doi: 10.1074/jbc.M407963200

154. Akhondzadeh S, Sabet MS, Harirchian MH, Gougol A,
Yekehtaz H, Alimardani R, et al. A 22-week, multicenter, randomized, double-blind controlled trial of Crocus sativus in the treatment of mild-to-moderate Alzheimer's disease. Hum Psychopharmacol. 2010b;207(4):637-43. doi: 10.1002/ hup. 2412

155. Farokhnia M, Shafiee Sabet M, Iranpour N, Gougol A, Yekehtaz $\mathrm{H}$, Alimardani $\mathrm{R}$, et al. Comparing the efficacy and safety of Crocus sativus $\mathrm{L}$. with memantine in patients with moderate to severe Alzheimer's disease: a double-blind randomized clinical trial. Hum Psychopharmacol. 2014;29(4):351-59. doi: 10.1002/hup. 2412

156. Akhondzadeh S, Sabet MS, Harirchian M, Togha M, Cheraghmakani $\mathrm{H}$, Razeghi S, et al. Saffron in the treatment of patients with mild to moderate Alzheimer's disease: a 16-week, randomized and placebo-controlled trial. J Clin Pharm Ther. 2010a;35(5):581-8. doi: 10.1111/j.1365-2710.2009.01133.x

157. Steiner GZ, Yeung A, Liu JX, Camfield DA, Blasio FM, Pipingas $A$, et al. The effect of Sailuotong (SLT) on neurocognitive and cardiovascular function in healthy adults: a randomised, double-blind, placebo controlled crossover pilot trial. BMC Complement Altern Med. 2015;16(1):15. doi: 10.1186/ s12906-016-0989-0

158. Tsolaki M, Karathanasi E, Lazarou I, Dovas K, Verykouki E, Karacostas A, et al. Efficacy and safety of Crocus sativus L. in patients with mild cognitive impairment: one year single-blind randomized, with parallel groups, clinical trial. J Alzheimers Dis. 2016;54(1):129-33. doi: 10.3233/JAD-160304

159. Dashti-r M, Zeinali F, Anvari M, Hosseini S. Saffron (Crocus sativus L.) extract prevents and improves D-galactose and NaNO2 induced memory impairment in mice. EXCLI J. $2012 ; 11: 328$

160. Ochiai T, Shimeno H, Mishima K-i, Iwasaki K, Fujiwara M, Tanaka $\mathrm{H}$, et al. Protective effects of carotenoids from saffron on neuronal injury in vitro and in vivo. Biochim Biophys Acta. 2007;1770(4):578-84. doi: 10.1016/j.bbagen.2006.11.012

161. Tashakori-Sabzevar F, Hosseinzadeh H, Sadat Motamedshariaty V, Reza Movassaghi A, Ahmad Mohajeri S. Crocetin attenuates spatial learning dysfunction and hippocampal injury in a model of vascular dementia. Curr Neurovasc Res. 2013;10(4):325334. doi: 10.2174/15672026113109990032

162. Hosseinzadeh H, Sadeghnia HR, Ghaeni FA, Motamedshariaty VS, Mohajeri SA. Effects of saffron (Crocus sativus L.) and its active constituent, crocin, on recognition and spatial memory after chronic cerebral hypoperfusion in rats. Phytother Res. 2012;26(3):381-386. doi: 10.1002/ptr.3566

163. Zheng YQ, Liu JX, Wang JN, Xu L. Effects of crocin on reperfusion-induced oxidative/nitrative injury to cerebral microvessels after global cerebral ischemia. Brain Res. 2007;1138:86-94. doi: 10.1016/j.brainres.2006.12.064

164. Khalili M, Hamzeh F. Effects of active constituents of Crocus sativus L., crocin on streptozocin-induced model of sporadic Alzheimer's disease in male rats. Iran Biomed J. 2010;14(12):59.

165. Naghizadeh B, Mansouri M, Ghorbanzadeh B, Farbood Y, Sarkaki A. Protective effects of oral crocin against intracerebroventricular streptozotocin-induced spatial memory deficit and oxidative stress in rats. Phytomedicine. 2013;20(6):537-42. doi: 10.1016/j.phymed.2012.12.019

166. amaddonfard E, Farshid AA, Asri-Rezaee S, Javadi S, Khosravi V, Rahman B, et al. Crocin improved learning and memory impairments in streptozotocin induced diabetic rats. Iran J Basic Med Sci. 2013;16(1):91-100.

167. Moshahid Khan M, Ahmad A, Yusuf S, Islam F. Neuroprotective efficacy of Nardostachys jatamansi and crocetin in conjunction with selenium in cognitive impairment. Neurol Sci. 2012;33(5):1011-20. doi: 10.1007/s10072-011-0880-1.

168. Bandegi AR, Rashidy-Pour A, Vafaei AA, Ghadrdoost B. Protective effects of Crocus sativus L. extract and crocin 
against chronic-stress induced oxidative damage of brain, liver and kidneys in rats. Adv Pharm Bull. 2014;4(Suppl 2):493-9. doi: 10.5681/apb.2014.073.

169. Ghadrdoost B, Vafaei AA, Rashidy-Pour A, Hajisoltani R, Bandegi AR, Motamedi F, et al. Protective effects of saffron extract and its active constituent crocin against oxidative stress and spatial learning and memory deficits induced by chronic stress in rats. Eur J Pharmacol. 2011;667(1-3):222-9. doi: 10.1016/j.ejphar.2011.05.012.

170. El-Beshbishy HA, Hassan MH, Aly HA, Doghish AS, Alghaithy AA. Crocin "saffron" protects against beryllium chloride toxicity in rats through diminution of oxidative stress and enhancing gene expression of antioxidant enzymes. Ecotoxicol Environ Saf. 2012;83:47-54. doi: 10.1016/j.ecoenv.2012.06.003

171. Pitsikas N, Zisopoulou S, Tarantilis PA, Kanakis CD, Polissiou MG, Sakellaridis N. Effects of the active constituents of Crocus sativus L., crocins on recognition and spatial rats' memory. Behav Brain Res. 2007;183(2):141-6. doi: 10.1016/j. bbr.2007.06.001

172. Pitsikas N, Sakellaridis N. Crocus sativus L. extracts antagonize memory impairments in different behavioural tasks in the rat. . Behav Brain Res. 2006;173(1):112-5. doi: 10.1016/j. bbr.2006.06.005

173. Zhang Y, Shoyama Y, Sugiura M, Saito H. Effects of Crocus sativus L. on the ethanol-induced impairment of passive avoidance performances in mice. Biol Pharm Bull. 1994;17(2):217-21. doi: 10.1248/bpb.17.217

174. Sugiura M, Shoyama Y, Saito H, Nishiyama N. Crocin improves the ethanol-induced impairment of learning behaviors of mice in passive avoidance tasks. Proceedings of the Japan Academy, Series B. 1995;71(10):319-24. doi:10.2183/pjab.71.319

175. Abe K, Sugiura M, Yamaguchi S, Shoyama Y, Saito H. Saffron extract prevents acetaldehyde-induced inhibition of longterm potentiation in the rat dentate gyrus in vivo. Brain Res. 1999;851(1-2):287-9. doi: 10.1016/s0006-8993(99)02174-5

176. Walton J, Wang MX. APP expression, distribution and accumulation are altered by aluminum in a rodent model for Alzheimer's disease. J Inorg Biochem. 2009;103(11):1548-54. doi: 10.1016/j.jinorgbio.2009.07.027

177. Xu Y, Wang Z, You W, Zhang X, Li S, Barish PA, et al. Antidepressant-like effect of trans-resveratrol: involvement of serotonin and noradrenaline system. Eur Neuropsychopharmacol. 2010;20(6):405-13. doi: 10.1016/j. euroneuro.2010.02.013

178. Yokel RA. Blood-brain barrier flux of aluminum, manganese, iron and other metals suspected to contribute to metal-induced neurodegeneration. J Alzheimers Dis. 2006;10(2-3):223-53. doi: 10.3233/jad-2006-102-309

179. Zhang ZJ, Qian YH, Hu HT, Yang J, Yang GD. The herbal medicine Dipsacus asper Wall extract reduces the cognitive deficits and overexpression of $\beta$-amyloid protein induced by aluminum exposure. Life Sci. 2003;73(19):2443-54. doi: 10.1016/s0024-3205(03)00649-0

180. Sethi P, Jyoti A, Singh R, Hussain E, Sharma D. Aluminiuminduced electrophysiological, biochemical and cognitive modifications in the hippocampus of aging rats. Neurotoxicology. 2008;29(6):1069-79. doi: 10.1016/j. neuro.2008.08.005

181. Sharma D, Sethi P, Hussain E, Singh R. Curcumin counteracts the aluminium-induced ageing-related alterations in oxidative stress, $\mathrm{Na}+, \mathrm{K}+$ ATPase and protein kinase $\mathrm{C}$ in adult and old rat brain regions. Biogerontology. 2009;10(4):489-502. doi: 10.1007/s10522-008-9195-x

182. Tripathi S, Mahdi AA, Nawab A, Chander R, Hasan M, Siddiqui MS, Mahdi F, et al. Influence of age on aluminum induced lipid peroxidation and neurolipofuscin in frontal cortex of rat brain: a behavioral, biochemical and ultrastructural study. Brain Res. 2009;1253:107-16.doi:10.1016/j.brainres.2008.11.060
183. Butterfield DA, Abdul HM, Newman S, Reed T. Redox proteomics in some age-related neurodegenerative disorders or models thereof. NeuroRx. 2006;3(3):344-57. doi: 10.1016/j. nurx.2006.05.003

184. Murali G, Panneerselvam C. Age-associated oxidative macromolecular damages in rat brain regions: role of glutathione monoester. J Gerontol A Biol Sci Med Sci. 2007;62(8):824-30. doi: 10.1093/gerona/62.8.824

185. Forster MJ, Dubey A, Dawson KM, Stutts WA, Lal H, Sohal RS. Age-related losses of cognitive function and motor skills in mice are associated with oxidative protein damage in the brain. Proc Natl Acad Sci U S A. 1996;93(10):4765-9. doi: 10.1073/pnas.93.10.4765

186. Gorini A, Ghigini B, Villa R. Acetylcholinesterase activity of synaptic plasma membranes during ageing: effect of L-acetylcarnitine. Demantia. 1996;7(3):147-54. doi: $10.1159 / 000106870$

187. Geromichalos GD, Lamari FN, Papandreou MA, Trafalis DT, Margarity M, Papageorgiou A, et al. Saffron as a source of novel acetylcholinesterase inhibitors: molecular docking and in vitro enzymatic studies. J Agric Food Chem. 2012;60(24):6131-8. doi: $10.1021 /$ jf300589c

188. Ochiai T, Ohno S, Soeda S, Tanaka H, Shoyama Y, Shimeno $\mathrm{H}$. Crocin prevents the death of rat pheochromyctoma (PC12) cells by its antioxidant effects stronger than those of $\alpha$-tocopherol. Neurosci Lett. 2004;362(1):61-4. doi; 10.1016/j. neulet.2004.02.067

189. Mehri S, Abnous K, Mousavi SH, Shariaty VM, Hosseinzadeh $\mathrm{H}$. Neuroprotective effect of crocin on acrylamideinduced cytotoxicity in PC12 cells. Cell Mol Neurobiol. 2012;32(2):227-35. doi: 0.1007/s10571-011-9752-8

190. Mousavi SH, Tayarani N, Parsaee H. Protective effect of saffron extract and crocin on reactive oxygen species-mediated high glucose-induced toxicity in PC12 cells. Cell Mol Neurobiol. 2010;30(2):185-91. doi: 10.1007/s10571-009-9441-z

191. Kannan K, Jain SK. Oxidative stress and apoptosis. Pathophysiology. 2000;7(3):153-63. doi: 10.1016/s09284680(00)00053-5

192. Scorrano L, Korsmeyer SJ. Mechanisms of cytochrome C release by proapoptotic BCL-2 family members. Biochem Biophys Res Commun. 2003;304(3):437-44. doi: 10.1016/ s0006-291x(03)00615-6

193. Zhang G-F, Zhang Y, Zhao G. Crocin protects PC12 cells against MPP+-induced injury through inhibition of mitochondrial dysfunction and ER stress. Neurochem Int. 2015;89:101-10. doi: 10.1016/j.neuint.2015.07.011

194. Nam KN, Park YM, Jung HJ, Lee JY, Min BD, Park SU, et al. Anti-inflammatory effects of crocin and crocetin in rat brain microglial cells. Eur J Pharmacol. 2010;648(1-3):110-16. doi: 10.1016/j.ejphar.2010.09.003

195. Hosseinzadeh H, Shakib SS, Sameni AK, Taghiabadi E. Acute and subacute toxicities of safranal, a constituent of saffron, in mice and rats. Iran J Pharm Res. 2011;13(44):S122.

196. Hosseinzadeh H, Shariaty VM, Sameni A. Acute and sub-acute toxicity of crocin, aconstituent of Crocus sativus L.(Saffron), in mice and rats. January 2010.

197. Mohajeri D, Mousavi G, Mesgari M, Doustar Y, Khayat Nouri M. Subacute toxicity of Crocus sativus L.(saffron) stigma ethanolic extract in rats. Am J Pharmacol Toxicol. 2007;2(4):189-93. doi: 10.3844/ajptsp.2207.189.193

198. Khayatnouri M, Safavi SE, Safarmashaei S, Babazadeh D, Mikailpourardabili B. The effect of saffron orally administration on spermatogenesis index in rat. Adv Environ Biol. 2011;5:1514-21.

199. Taheri F, Zahra Bathaie S, Ashrafi M, Ghasemi E. Assessment of Crocin Toxicity on the Rat Liver. Modares Journal of Medical Sciences: Pathobiology. 2014;17(3).

200. Riahi-Zanjani B, Balali-Mood M, Mohammadi E, Badie-Bostan 
H, Memar B, Karimi G. Safranal as a safe compound to mice immune system. Avicenna J Phytomed. 2015;5(5):441.

201. Muosa F, AL-Rekabi K, Askar S, Yousif E. Evaluation of the toxic effect of ethanolic extract of saffron in male mice after subchronic exposure. Donnish J Pharm Pharmacol. 2015;1:17.

202. Bostan HB, Mehri S, Hosseinzadeh H. Toxicology effects of saffron and its constituents: a review. Iran J Basic Med Sci. 2017;20(2):110. doi: 10.22038/ijbms.2017.8230

203. Khan M, Hanif MA, Ayub MA, Jilani MI, Chatha SAS. Saffron. Medicinal Plants of South Asia: Elsevier; 2020:587-600.

204. Modaghegh M-H, Shahabian M, Esmaeili HA, Rajbai O, Hosseinzadeh H. Safety evaluation of saffron (Crocus sativus) tablets in healthy volunteers. Phytomedicine. 2008;15(12):1032-7. doi: 10.1016/j.phymed.2008.06.003

205. Ayatollahi H, Javan AO, Khajedaluee M, Shahroodian M, Hosseinzadeh H. Effect of Crocus sativus L.(saffron) on coagulation and anticoagulation systems in healthy volunteers. Phytother Res. 2014; 28(4):539-43. doi 10.1002/ptr.5021

206. Mohamadpour AH, Ayati Z, Parizadeh MR, Rajbai O, Hosseinzadeh H. Safety evaluation of crocin (a constituent of saffron) tablets in healthy volunteers. Iran J Basic Med Sci. 2013;16(1):39.

207. Ajam M, Reyhani T, Roshanravan V, Zare Z. Increased miscarriage rate in female farmers working in saffron fields: a possible effect of saffron toxicity. Asia Pac J Med Toxicol. 2014;3(2):73-5. doi: 10.22038/apjmt.2014.3047

208. Sadraei H, Ghannadi A, Takei-bavani M. Effects of Zataria multiflora and Carum carvi essential oils and hydroalcoholic extracts of Passiflora incarnata, Berberis integerrima and Crocus sativus on rat isolated uterus contractions. International Journal of Aromatherapy. 2003;13(2-3):121-7. doi: 10.1016/ S0962-4562(03)00092-4

209. Inoue E, Shimizu Y, Shoji M, Tsuchida H, Sano Y, Ito C. Pharmacological properties of $\mathrm{N}-095$, a drug containing red ginseng, polygala root, saffron, antelope horn and aloe wood. Am J Chin Med. 2005; 33(01):49-60. doi 10.1142/ S0192415X05002655.

210. Ahmadi S, Azhari S, Jafarzadeh H, Rakhshandeh H, Mazlom $R$. The effect of oral capsules of saffron on anxiety and fatigue during the first stage of labor. SSU_Journals. 2015;23(2):191526.

211. Ahmadi S, Azhari S, Rakhshandeh H, Jaafarzadeh H, Mazlum S. Evaluation of the effect of saffron oral capsules on duration of the active phase of labor first stage. Iran J Reprod Med. 2014;12(6):44.

212. Kamalipour M, Akhondzadeh S. Cardiovascular effects of saffron: an evidence-based review. Journal of Tehran Heart Center. 2011 6(2):59-61. 